Article

\title{
Detrital Zircon Provenance Analysis in the Central Asian Orogenic Belt of Central and Southeastern Mongolia-A Palaeotectonic Model for the Mongolian Collage
}

\author{
Wilfried Winkler ${ }^{1, *}$, Denise Bussien ${ }^{1,2}$, Munktsengel Baatar ${ }^{3}$ (D) Chimedtseren Anaad $^{3}$ \\ and Albrecht von Quadt ${ }^{1}$ \\ 1 Department of Earth Sciences, ETH Zurich, 8092 Zurich, Switzerland; \\ denise.bussien.grosjean@gmail.com (D.B.); albrecht.vonquadt@erdw.ethz.ch (A.v.Q.) \\ 2 Aba Géol SA, 1530 Payerne, Switzerland \\ 3 School of Geology and Mining, Mongolian University of Science and Technology, \\ Ulaanbaatar 120646, Mongolia; tsengel@must.edu.mn (M.B.); chimedtserena@yahoo.com (C.A.) \\ * Correspondence: wilfried.winkler@erdw.ethz.ch
}

Received: 24 June 2020; Accepted: 21 September 2020; Published: 2 October 2020

\begin{abstract}
Our study is aimed at reconstructing the Palaeozoic-early Mesozoic plate tectonic development of the Central Asian Orogenic Belt in central and southeast Mongolia (Gobi). We use sandstone provenance signatures including laser ablation $\mathrm{U}-\mathrm{Pb}$ ages of detrital zircons, their epsilon hafnium isotope signatures, and detrital framework grain analyses. We adopt a well-established terran subdivision of central and southeastern Mongolia. However, according to their affinity and tectonic assemblage we group them into three larger units consisting of continental basement, rift-passive continental margin and arc elements, respectively. These are in today's coordinates: (i) in the north the late Cambrian collage from which the later Mongol-Okhotsk and the Central Mongolia-Erguna mountain ranges resulted, (ii) in the south a heterogeneous block from which the South Mongolia-Xin'gan and Inner Mongolia-Xilin belts developed, and (iii) in between we still distinguish the intra-oceanic volcanic arc of the Gurvansayhan terrane. We present a model for paleotectonic development for the period from Cambrian to Jurassic, which also integrates findings from the Central Asian Orogenic Belt in China and Russia. This mobilistic model implies an interplay of rift and drift processes, ocean formation, oceanic subduction, basin inversion, collision and suture formation in space and time. The final assemblage of the Central Asian Orogenic Belt occurred in Early Jurassic.
\end{abstract}

Keywords: Mongolia; detrital zircon; laser ablation U-Pb dating; Hafnium isotope-ratio; terrane definition; paleotectonic reconstruction

\section{Introduction}

The Central Asian Orogenic Belt or Altaid Belt records a long history of collage of different tectono-stratigraphic units (terranes), which amalgamated against the Siberian Craton from Early Neoproterozoic until Permian-Triassic (Figure 1; e.g., [1-9]). Accordingly, on Mongolian territory three main collisional events are recognized (Figure 1C): (i) a Neoproterzoic-Cambrian one in the NW and center (Tuva-Badrag terrane; Figure 1B), (ii) an arly Palaeozoic one in central Mongolia north of the Main Mongolian Lineament (MML, Figure 1B) (Central Mongolian terranes sensu [9]), and (iii) a Late Palaeozoic (Permian-Triassic) one in south-southeastern Mongolia, south of the MML (including 
the Gobi Altai, Mandalovoo, Gurvansayhan, Nuhetdavaa-Enshoo and Hutag Uul terranes sensu [10]; Figure 1C).
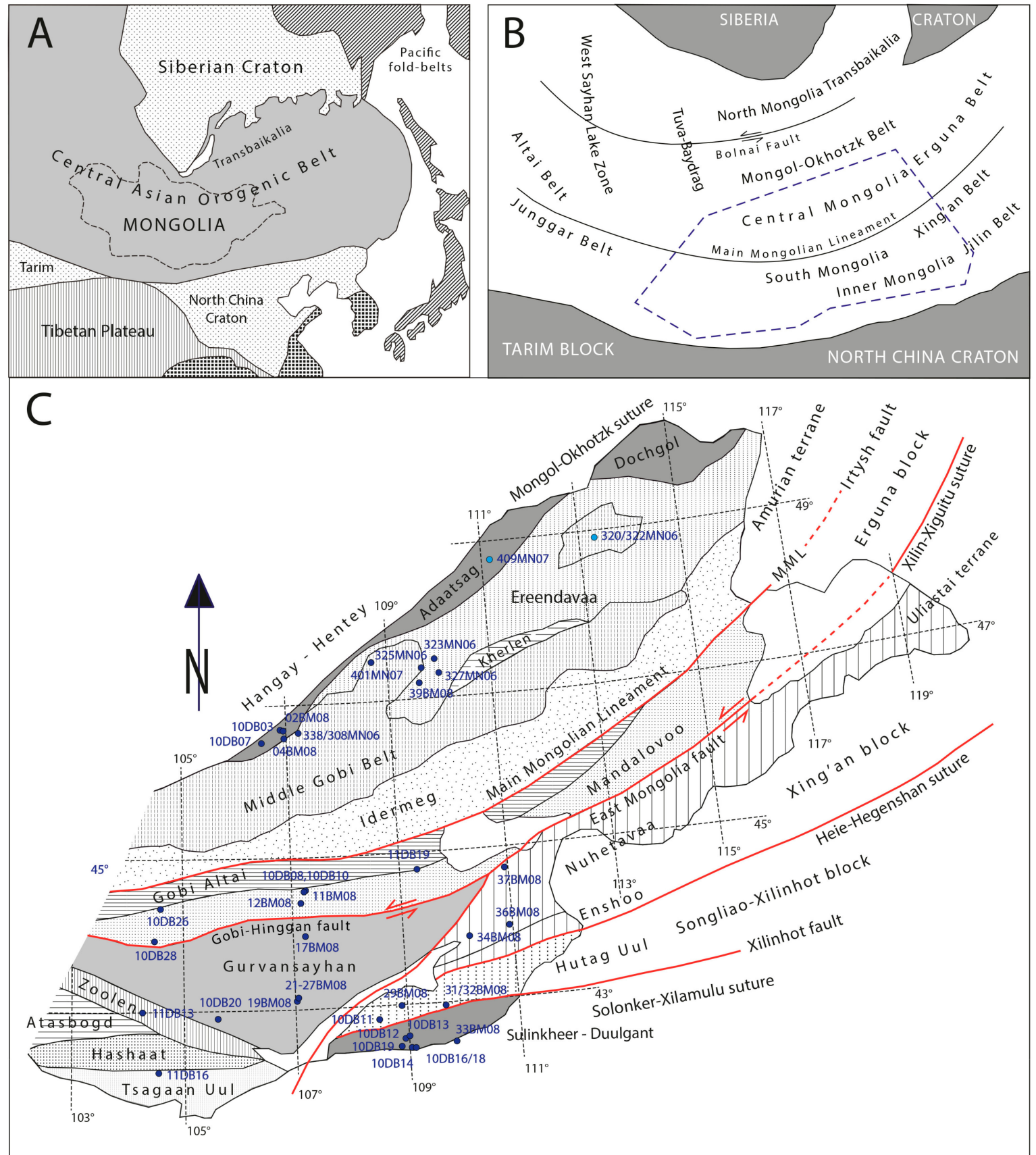

Figure 1. Index maps of orogens, terranes and sample locations in Mongolia. (A) Position of Central Asian Orogenic Belt. (B) Correlation of orogenic belts from Mongolia into adjacent countries. Adapted from [11-16]. Stippled frame corresponds to the approximate extent of subfigure (C). (C) Location of samples presented in this study based on the terrane subdivision of [10].

In South Mongolia, the colliding tectono-stratigraphic units comprised continental basement and oceanic terranes, seamounts, and continental and oceanic volcanic arcs nowadays preserved in continental slivers, sutures, arcs and accretionary complexes (e.g., [1,6,8,17-20]). Syn-tectonic Permian sediments were deposited in residual marine and continental (intermontane) basins [21,22]. Hence, the 
Permo-Triassic sediments suffered post-depositional tectonic deformation indicating the final collision occurred during the Jurassic (e.g., [23-26]).

The situation is further complicated by two other factors: (i) the Mongol-Okhotsk Ocean opened in Silurian within the central Mongolian collage and subsequently closed scissor-like from Triassic on eastward (e.g., [24,27-31]) and, (ii) during the entire Palaeozoic Siberia experienced steady $\left(>40^{\circ}\right)$ northward drift and an $\approx 75^{\circ}$ clockwise rotation from Middle Silurian to Permian [9,32]. In this respect it is a matter of debate, which terranes were when accreted, and as an integrated part of peri-Siberia they may have exercised rotations as well (e.g., [4,10,32]). With regard of point 1 , the duration of the Mongol-Okhotsk Ocean, there exist earlier models which suggest its existence since the late Neoproterozoic [33]. Recent studies, however, have demonstrated the independence of this ocean from the larger Paleo-Asian Ocean (e.g., [4,10,11,27-31]), because it opened later.

The present work is a study of the central Mongolian and southeastern Mongolian terranes by analysing detrital modes and detrital zircons from sandstones comprised in the various terranes (Figure 1B,C). We suggest that ages and Hf-isotope signatures of the detrital zircons, gained by laser-ablation ICP-MS measurements, will allow to define the basement and volcanic sources of the terranes and discuss their plate-tectonic character [34-37]. Hafnium isotope ratios $\left({ }^{176} \mathrm{Hf} /{ }^{177} \mathrm{Hf}\right)$ in dated zircon grains may allow identification of the nature of the magmatic source rocks with respect to their derivation from depleted mantle, recycled continental crust or mixtures (e.g., [36]). Thus, giving arguments for plate tectonic processes working during the magmatic activity like rifting, passive continental margin and subduction settings.

Parts of the data from the Hangay-Hentey, Adaatsag and Ereendavaa terranes within the Mongol-Okhotsk Belt were discussed in earlier papers [24,31]. With the present study we can summerize the Palaeozoic tectonic history of central and southeastern Mongolia, and we attempt to sketch a palaeotectonic model for the central and southeastern Mongolian transect of the Central Asian Orogenic Belt. We expect that our hypothetical model will be tested and probably modified by further research in this area.

\section{Geological Framework of Central and Southeastern Mongolia}

Depending on scopes, scales and methods applied, numerous studies of the area exist, which use different terrane names, but mostly rely on Badarch et al. [10]. We also aim for the most accurate possible correlation of the Mongolian terranes with the established tectonic-stratigraphic units in China and Russia [6,8,14,37-42] with our results. The doubled Kipchak-arc model ([33,42]), and references therein) was modified during the last decades towards a model inferring the time-stepped closure of oceanic basins within the larger Palaeo-Asian Ocean driven by the collision of continental basement with arc complexes and suturing [1,6,9,43-46]. A main structure is the MML, which is assumed to coincide with the former Early Palaeozoic southern margin (in modern coordinates) of the late Cambrian-Ordovician peri-Siberian collage [1,6,9]. However, across the northeastern boundary of Mongolia within the Chinese and Russian territory this structure was not yet described.

\subsection{Terranes North of the MML}

\subsubsection{Adaatsag Terrane}

It comprises a highly deformed and metamorphosed ophiolite-bearing shaley association representing the suture of the Mongol-Okhotsk Belt with Ordovician shales, quartzites, sandstones, cherts and metavolcanic rocks. Mélanges contain serpentinites, fragments of serpentinized dunite and hartzburgite, gabbro, metabasalts and tholeiitic basalts [1,29]. From our detrital zircon dating results it becomes evident that the Addaatsag terrane comprises also deformed Permian maximum age sandstones (see Figure 2A and [24]). 
Table 1. Samples listed by terranes, lithology, mapped age, maximum age according to detrital zircon dating and methods applied in the present study.

\begin{tabular}{|c|c|c|c|c|c|c|c|}
\hline Terrane & Sample No. & Group/Formation & $\begin{array}{l}\text { Colour Code on 1:1.5 Million } \\
\text { Scale Geological Map of } \\
\text { Erdenechimeg et al. [47] }\end{array}$ & Outcrop Lithology/Facies & Mapped Age & $\begin{array}{c}\text { Maximum } \\
\text { Depositional Age } \\
\text { (Inferred According to } \\
\text { Detrital Zircon Ages) }\end{array}$ & $\begin{array}{l}\text { Methods: Detrital } \\
\text { Zircons DZ, } \\
\text { Sandstone Modal } \\
\text { Analysis MA }\end{array}$ \\
\hline \multirow{5}{*}{ Adaatsag } & 02BM08 & Bayantsagaan Fm & $\mathrm{C} 1-2 b c$ & \multirow{5}{*}{$\begin{array}{l}\text { Greenish-grey shales, splintery breaking } \\
\text { Very coarse sandstones with large-scale } \\
\text { cross-bedding (slightly metamorphosed) } \\
\text { Greenish-brown massive shales with } \\
\text { bryozoans, brachiopods and echinoderms } \\
\text { Medium-bedded graded sandstones and } \\
\text { shales } \\
\text { Alluvial coarse sanstones and conglomerates }\end{array}$} & Carboniferous & Ordovician-Silurian & DZ \\
\hline & 04BM08 & Bayantsagaan Fm & $\mathrm{C} 1-2 b c$ & & Carboniferous & Permian & $\mathrm{DZ}$ \\
\hline & 10DB03 & Nomgon Fm & S-Dad or S-Dnn & & Carboniferous & Permian & $\mathrm{DZ}, \mathrm{MA}$ \\
\hline & 10DB07 & Bayantsagaan Fm & $C 1-2-b c$ & & Devonian & Permian & $\mathrm{DZ}, \mathrm{MA}$ \\
\hline & 409MN07 & Urtiin-Gol Fm & J2-3-ug & & Jurassic & Confirmed & $\mathrm{DZ}, \mathrm{MA}$ \\
\hline \multirow{9}{*}{ Ereendavaa } & 320MN06 & Gazar Fm & $\mathrm{P} 1-2 g z$ & \multirow{2}{*}{$\begin{array}{c}\text { Sandstones, yellowish-grey } \\
\text { Coarse-grained immature sandstones, } \\
\text { greenish-grey }\end{array}$} & Permian & Permian - E-Triassic & $\mathrm{DZ}, \mathrm{MA}$ \\
\hline & $322 \mathrm{MN} 06$ & Sharil Fm & $\mathrm{J} 3-\mathrm{s} r$ & & Jurassic & Confirmed & $\mathrm{DZ}$ \\
\hline & 323MN06 & Kavchuu Fm & $\mathrm{D} 1-h b$ & Coarse-grained sandstones, greenish-grey & Devonian & Ordovician-Silurian & $\mathrm{DZ}, \mathrm{MA}$ \\
\hline & $325 \mathrm{MN} 06$ & Mungut-Uul Fm & T2-3-mu & Blueish-gray, coarse grained sandstone & Triassic & Permian & $\mathrm{DZ}, \mathrm{MA}$ \\
\hline & 327MN06 & Nariintai Fm & $\mathrm{D} 1-n r$ & $\begin{array}{l}\text { Light grey sandstones, slightly } \\
\text { metamorphosed }\end{array}$ & Devonian & Ordovician & $\mathrm{DZ}, \mathrm{MA}$ \\
\hline & 308MN06 & Bayantsagaan Fm & $\mathrm{C} 1-2 b c$ & Greenish-grey, medium grained sandstone & Permian & Confirmed & DZ \\
\hline & 338MN06 & Bayantsagaan Fm & $C 1-2-b c$ & $\begin{array}{l}\text { Turbiditic sandstone in spotted (bioturbated) } \\
\text { green shales }\end{array}$ & Carboniferous & L.Carb. - Permian & $\mathrm{DZ}, \mathrm{MA}$ \\
\hline & 39BM08 & Zamttolgoi Fm & $\mathrm{NO} 2-z m$ & $\begin{array}{l}\text { Coarsening upward quartz-rich turbiditic } \\
\text { sandstones with prasinite sill }\end{array}$ & Devonian & Confirmed & $\mathrm{DZ}, \mathrm{MA}$ \\
\hline & 401MN07 & Ulz Fm & P2-ul & Siliceous shales and turbiditic sandstones & Permian & Confirmed & $\mathrm{DZ}$ \\
\hline Goti Altai & 11DB19 & Dushovoo Fm & $\mathrm{C} 2-\mathrm{do}_{0}-2-1$ & $\begin{array}{l}\text { Greenish-grey and minor reddish shales with } \\
\text { coarse (turbiditic) sandstone intercalations }\end{array}$ & Devonian & Carboniferous & $\mathrm{DZ}, \mathrm{MA}$ \\
\hline \multirow{6}{*}{ Mandalovoo } & 10DB08 & Khutul-Us-Khudag Fm & $\mathrm{D} 1-h u$ & $\begin{array}{l}\text { Volcaniclastic sandstone intercalated } \\
\text { between quartz-bearing conglomerates, } \\
\text { overlying bioturbated fossiliferous } \\
\text { limestones and topped by bioturbated } \\
\text { crinoidal limestones (Thalassinoides) }\end{array}$ & Early Devonian & Confirmed & Confirmed \\
\hline & 10DB10 & Khutul-Us-Khudag Fm & $\mathrm{D} 1-h u$ & $\begin{array}{l}\text { Quartz-rich conglomerate with volcanic } \\
\text { pebbles }\end{array}$ & Devonian & No data & MA \\
\hline & 10DB26 & Mangal-Ovoo Fm & O3-S-mo & $\begin{array}{l}\text { Greenish-grey, highly concentrated turbitity } \\
\text { flow beds, partly slumped in finer facies }\end{array}$ & Ordovician-Silurian & Silurian & $\mathrm{DZ}, \mathrm{MA}$ \\
\hline & 10DB28 & Djadokhta Fm & K2-bg & $\begin{array}{c}\text { Red shales and sandstones with saurian } \\
\text { bones }\end{array}$ & Cretaceous & E. Cretaceous & DZ \\
\hline & 11BM08 & Khutal-Us-Khudag Fm & D1-hu & $\begin{array}{l}\text { Sandstones and conglomerates rich in } \\
\text { vein-quartz pebbles with coarse } \\
\text { cross-bedding; fan delta association }\end{array}$ & Devonian & Silurian-E. Devonian & $\mathrm{DZ}$ \\
\hline & 12BM08 & Tal Fm & $C 1-t l$ & $\begin{array}{c}\text { Dark greenish-brown turbiditic sandstones } \\
(30-50 \mathrm{~cm}) \text { rich in red volcanic lithoclasts } \\
\text { and plagioclase }\end{array}$ & Carboniferous & Confirmed & $\mathrm{DZ}, \mathrm{MA}$ \\
\hline
\end{tabular}


Table 1. Cont.

\begin{tabular}{|c|c|c|c|c|c|c|c|}
\hline Terrane & Sample No. & Group/Formation & $\begin{array}{l}\text { Colour Code on 1:1.5 Million } \\
\text { Scale Geological Map of } \\
\text { Erdenechimeg et al. [47] }\end{array}$ & Outcrop Lithology/Facies & Mapped Age & $\begin{array}{c}\text { Maximum } \\
\text { Depositional Age } \\
\text { (Inferred According to } \\
\text { Detrital Zircon Ages) }\end{array}$ & $\begin{array}{l}\text { Methods: Detrital } \\
\text { Zircons DZ, } \\
\text { Sandstone Modal } \\
\text { Analysis MA }\end{array}$ \\
\hline \multirow{5}{*}{ Gurvansayhan } & 17BM08 & Manlai Fm & K1-mn & Conglomerates, sandstones and red shales & Cretaceous & Early Cretaceous & $\mathrm{DZ}$ \\
\hline & 19BM08 & Alagbayan Gr & $\mathrm{DA} 4 \mathrm{~b} / \mathrm{c}^{*}$ & Andesltic sandstone & Late Devonian & No data & MA \\
\hline & 21/22BM08 & Sainshanhuadag Fm & CS2a * & $\begin{array}{l}\text { Fining-upward series of volcaniclastic } \\
\text { (andesitic) conglomerates and sandstones, } \\
\text { overlying ignimbrite }\end{array}$ & Tournaisian-Visean & Carboniferous & $\mathrm{DZ}, \mathrm{MA}$ \\
\hline & 26BM08 & Alagbayan Gr & $\mathrm{DA} 2 \mathrm{~b} *$ & Volcaniclastic sandstone & Devonian & Middle-Late Devonian & $\mathrm{DZ}$ \\
\hline & 27BM08 & Alagbayan Gr & $\mathrm{DA} 2 \mathrm{~b}$ * & Volcaniclastic sandstone & Devonian & $\begin{array}{c}\text { Late } \\
\text { Devonian-Mississippian }\end{array}$ & $\mathrm{DZ}$ \\
\hline Atasbogd-Zoolen & $11 \mathrm{DB} 13$ & Talynmeltes Fm & D1-2-tm & Green volcaniclastic sandstone & $\begin{array}{l}\text { L. Silurian -E. } \\
\text { Devonian }\end{array}$ & Late Devonian & $\mathrm{DZ}$ \\
\hline Tsagaan Uul & 11DB16 & Tavankhudag Fm & D1-th & Massive dark green arkosic sandstones & Devonian & Late Devonian & $\mathrm{DZ}, \mathrm{MA}$ \\
\hline \multirow{3}{*}{$\begin{array}{l}\text { Nuhetdavaa } \\
\text { (-Enshoo) }\end{array}$} & 34BM08 & Sangiindalai Fm & O3-sd & $\begin{array}{c}\text { Massive brownish coarse sandstones } \\
\text { (turbidites) assosiated with green siliceous } \\
\text { shales }\end{array}$ & $\begin{array}{c}\text { M.-I. } \\
\text { Carboniferous }\end{array}$ & Permian-E. Triassiac & $\mathrm{DZ}, \mathrm{MA}$ \\
\hline & 36BM08 & Ulziit-Uul Fm & C2-uu & $\begin{array}{l}\text { Green and minor red shales intercalated by } \\
\text { dark greenish-grey graded sandstones } \\
\text { (presumaby turbiditic), few breccias }\end{array}$ & Carboniferous & Ordovician & $\mathrm{DZ}, \mathrm{MA}$ \\
\hline & 37BM08 & Gunbajan Fm & $\mathrm{C} 1-g b$ & $\begin{array}{l}\text { Red and green spotted shales associated } \\
\text { with lenticular poorly sorted red sand- and } \\
\text { siltstones (presumably low energy } \\
\text { meandring fluvial) }\end{array}$ & Carboniferous & No data & MA \\
\hline \multirow{4}{*}{ Hutag Uul } & 10DB11 & Lugiingol Fm & P2-lg & $\begin{array}{l}\text { Greenish-grey, generally fine-grained } \\
\text { turbiditic sandstones and shales }\end{array}$ & Devonian & Permian-E. Triassiac & $\mathrm{DZ}, \mathrm{MA}$ \\
\hline & 29BM08 & Uvgontolgoi Fm & P1-ut & $\begin{array}{l}\text { Thin-bedded, pyrite-bearing black shales } \\
\text { and thin » } 5-10 \mathrm{~cm} \text { thick sandstones }\end{array}$ & Permian & Confirmed & $\mathrm{DZ}$ \\
\hline & 31BM08 & Toli-Uul Fm & NP-E1-tu & $\begin{array}{l}\text { Greenish, coarse-grained volcanic litharenite, } \\
\text { turbiditic facies, alternating with sandstones } \\
\text { of 32BM08 type }\end{array}$ & Devonian & No data & MA \\
\hline & 32BM08 & Toli-Uul Fm & NP-E1-tu & $\begin{array}{c}\text { Light grey, coarse-grained arkosic sandstone, } \\
\text { turbiditic facies, overthrusted by Devonian } \\
\text { volcanics }\end{array}$ & Devonian & Permian & $\mathrm{DZ}, \mathrm{MA}$ \\
\hline \multirow{5}{*}{$\begin{array}{l}\text { Sulinkheer } \\
\text {-Duulgant }\end{array}$} & 10DB12 & Hetsuul Fm & P1-2hu & Graded quartz-sandstones & U. Permian & Confirmed & $\mathrm{DZ}, \mathrm{MA}$ \\
\hline & 10DB13 & Hetsuul Fm & $\mathrm{P} 1-2 h u$ & $\begin{array}{l}\text { Fine-grained quartz-sandstones, red shales, } \\
\text { and limestone intercalations }\end{array}$ & Carboniferous & Silurian-E. Devonian & $\mathrm{DZ}$ \\
\hline & 10DB14 & Agui-Uul Fm & C2-P1-au & $\begin{array}{l}\text { Red shales intercalated by coarse sandstones } \\
\text { and sand-supported conglomerates }\end{array}$ & Permian & Permian & $\mathrm{DZ}, \mathrm{MA}$ \\
\hline & 10DB18 & Agui-Uul Fm & C2-P1-au & $\begin{array}{l}\text { Quartz-rich sandstones associated with } \\
\text { green siliceous shales }\end{array}$ & Permian & No data & MA \\
\hline & 10DB19 & P1-2 & Unclassified & $\begin{array}{c}\text { Arkosic sanstones and grain-supported } \\
\text { conglomerates (cm-size pebbles, volcanics, } \\
\text { vein-quartz, radiolarite) }\end{array}$ & Permian & $\begin{array}{l}\text { Late Permian-Early } \\
\text { Triassic }\end{array}$ & $\mathrm{DZ}, \mathrm{MA}$ \\
\hline
\end{tabular}

* Denotes Drillhole Levels in the Oyu Dolgoi Mining District described by Dolgopolova et al. [48]. 

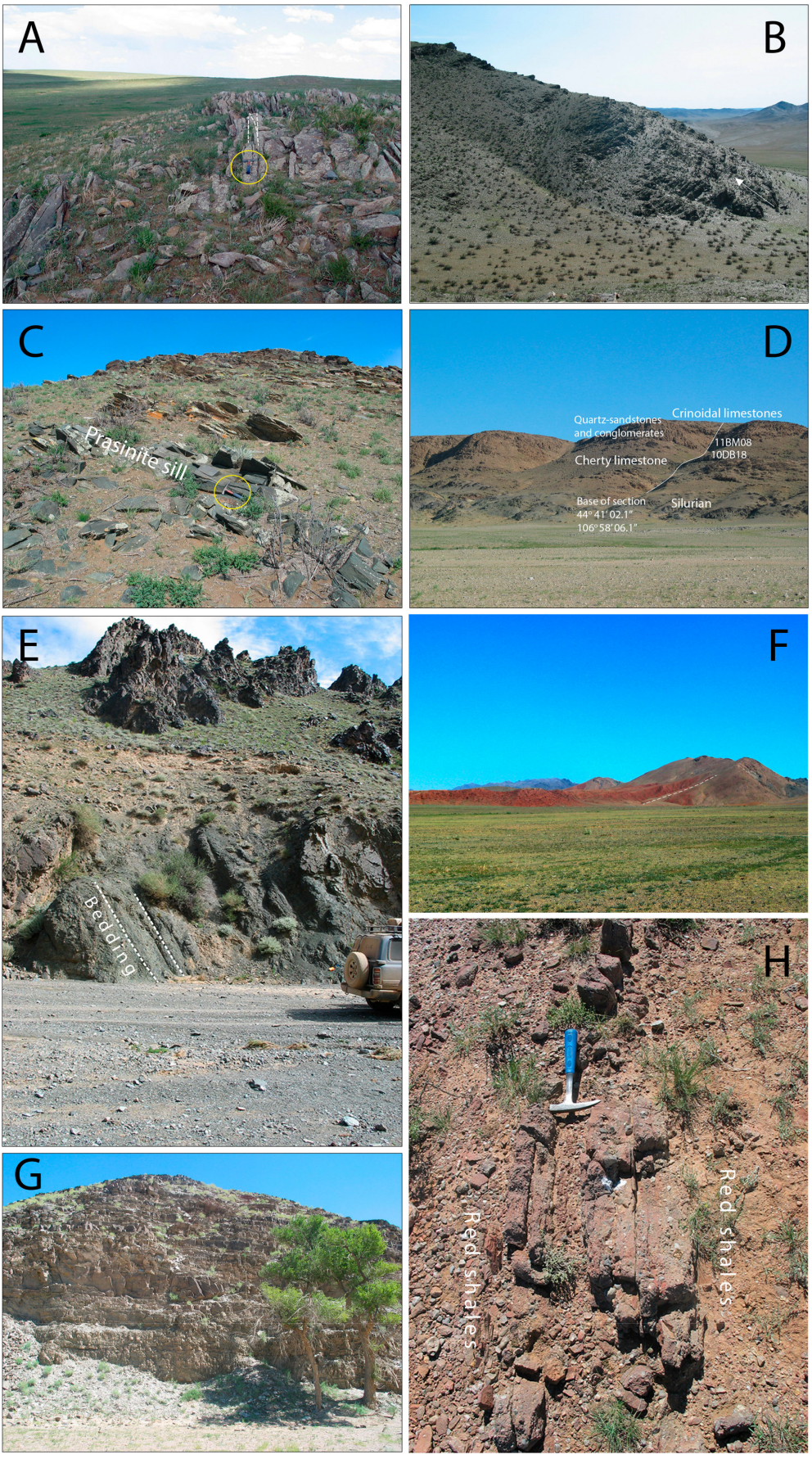

Figure 2. (A) Outcrop in Adaatsag terrane and locality of sandstone 04BM08 (Table 1, Figure 3), vertically bedded coarse sandstones and conglomerates with large scale cross-bedding, mapped "Carboniferous"; according to detrital zircon U-Pb results of Permian max. age; (B) Devonian series of Ereendavaa terrane showing a coarsening-upward series of quartz-rich turbiditic sandstones and shales at Bayantsogt Uul Mountain; (C) Detail of B with location of sample 39BM08 (Table 1) above a prasinitic sill (see hammer); (D) Devonian series of Mandalovoo terrane unconformably overlying Silurian shaley beds, from base to top volcaniclastic sandstones/conglomerates, bioturbated (Thalassinoides) cherty limestones (brachiopods, bryozoans), quartz sandstones and conglomerates in fan-delta facies (sample11BM08) with volcanoclastic intercalations (sample 10DB08); (E) Devonian-Carboniferous pebbly sandstones of the Gurvansayhan terrane bearing mainly clasts of basic volcanics, sandstones and shales, and spathic limestones; similar rocks we analysed from the Oyu Tolgoi mining district; (F) Cretaceous red beds onlapping the Gurvansayhan terrane in the Baron Gurvan area, view to SE, see 
results from sample 17BM08; (G) Slightly southward dipping turbiditic sandstones and shales of Hutag Uul terrane, locality of sample 10DB11, mapped as "Devonian", detrital zircon U-Pb infer a Permian-Early Triassic max. age; (H) Permian, vertically bedded, E-W striking red shales intercalated by coarse sandstones and conglomerates; younging to the $\mathrm{N}$, locality of sample 10DB14.

\subsubsection{Ereendavaa-Kherlen-Idermeg Terrane Group and Middle Gobi Belt}

In the Ereendavaa terrane, Silurian and Devonian marine shaley, sandy sediments and volcanics unconformably overly Palaeoproterozoic gneisses, Neoproterozoic schists, sandstones and marbles [10]. Recent results of Miao et al. ([11], this special volume) attest the presence of Proterozoic source rocks in the basement of the Ereendavaa terrane by the dating of detrital zircons in a quartzite formation deposited after $1.15 \mathrm{Ga}$. In a Devonian turbiditic sandstone succession (Bayantsogt Uul mountain, locality of sample 38BM08, Table 1) we recognised a prasinitic sill (Figure 2B,C), unfortunately not datable due to lack of zircons.

The Idermeg terrane consists of fossiliferous Neoproterozoic-Cambrian marbles, quartz-sandstones and conglomerates unconformably overlying gneisses, amphibolites and phyllites, which were intruded by Cambrian granites. The presence of Devonian-Permian and Triassic-Jurassic volcanic and sedimentary rocks we could not confirm. The Idermeg terrane is interpreted as a so-called microcontinent ([6], and references therein). In our view, this terrane represents a deeply eroded continental sliver like in the Baydrag terrane to the west as proposed by [16].

A former tectonic assembling of the Ereendavaa and Idermeg terranes (Figure 1C) at the Ordovician-Silurian transition is documented by the composition and ages derived from the Kherlen ophiolitic complex (eventually called Herlen). Miao et al. [16] dated gabbro and plagiogranite at $\sim 500 \mathrm{Ma}$ (SHRIMP zircon U-Pb) and post-collisional granites at $440 \mathrm{Ma}$ (Llandovery, early Silurian). These authors suggest that the Kherlen suture formed coevally and similarly with the Bayanhongor belt. Thus, this finding implies that the Baydrag and the Idermeg terranes during the Palaeozoic represented a common continental passive margin block related to the opening of the Mongol-Okhotsk Ocean [24,41].

In turn, in the Middle Gobi volcanic-plutonic belt Permian volcanic and sedimentary series unconformably top the abovementioned Palaeozoic turbiditic and pelagic sediments, and the Kherlen terrane (Figure 1C). Finally, flat-lying Lower Jurassic continental sandstones and conglomerates mark the youngest formations known from that terrane group [24].

In Russia, the above described Ereendavaa and Idermeg terranes continue in the form of the Precambrian Amurian superterrane bounded to the south by the MML [14,46] (Figure 1C). However, in contrast to Donskaya et al. [14] we suggest that these terranes represented the northern margin of the Mongol-Okhotsk Ocean and were subducted from Devonian on by the Mongol-Okhotsk Ocean plate.

\subsection{Terranes South of the MML}

\subsubsection{Gobi-Altai and Mandalovoo Terranes}

We genetically link here these terranes described by Badarch et al. [10] because we found similar detrital zircon age patterns and detrital modes in both (Figures 3 and 4). The Gobi Altai consists of Cambrian greenschist facies metamorphosed sandstones, mudstones, tuffs, and minor volcanic rocks, Ordovician to Silurian sandstones, Devonian to Mississippian conglomerates, sandstones, siltstones, fossiliferous limestone, andesite and tuff, overlain by Pennsylvanian, Permian to Triassic volcanic and sedimentary rocks $[11,17]$. The Mandalovoo terrane comprises Silurian to Carboniferous pelagic shales and turbiditic sandstones and conglomerates either rich in volcanic lithoclasts or quartz grains/pebbles. The Devonian series of the Mandalovoo terrane is also marked by the presence of shallow marine fossiliferous and bioturbated (Thalassinoides) crinoidal limestones. Devonian quartz-rich sandstones and conglomerates clearly show sand-dominated fluvio-deltaic facies (Figure 2D). In addition, Lamb 
and Badarch [17] and Badarch et al. [10] mention the presence of pillow basalts and Cretaceous post-accretionary sediments.

The Gobi Altai and Mandalovoo terranes may have their extension in the Erguna block in adjacent northeastern China (Figure 1). This contains Neoproterozoic (multi-) metamorphic basement (peak age $\approx 500 \mathrm{Ma}$; [39]), granitoids, Neoproterozoic meta-sediments, pre-Devonian sediments and Carboniferous strata [40]. However, Wu et al. [49] found that the great majority of the granitic intrusions in the Erguna block are Mesozoic in age related to the later subduction of the Palaeo-Pacific Ocean. Where the Gobi Altai and Mandalovoo terranes are not in contact with the Gurvansayhan terrane in southern Mongolia, Mandalovoo is separated from the Nuhetdavaa terrane by the blueschists and ophiolite-bearing Xilin-Xiguito suture [40]. Due to the completely different tectono-stratigraphic history of the Mandalovoo and Gurvansayhan terranes, their contact is the major Zumbayan (East Gobi) fault zone [15].

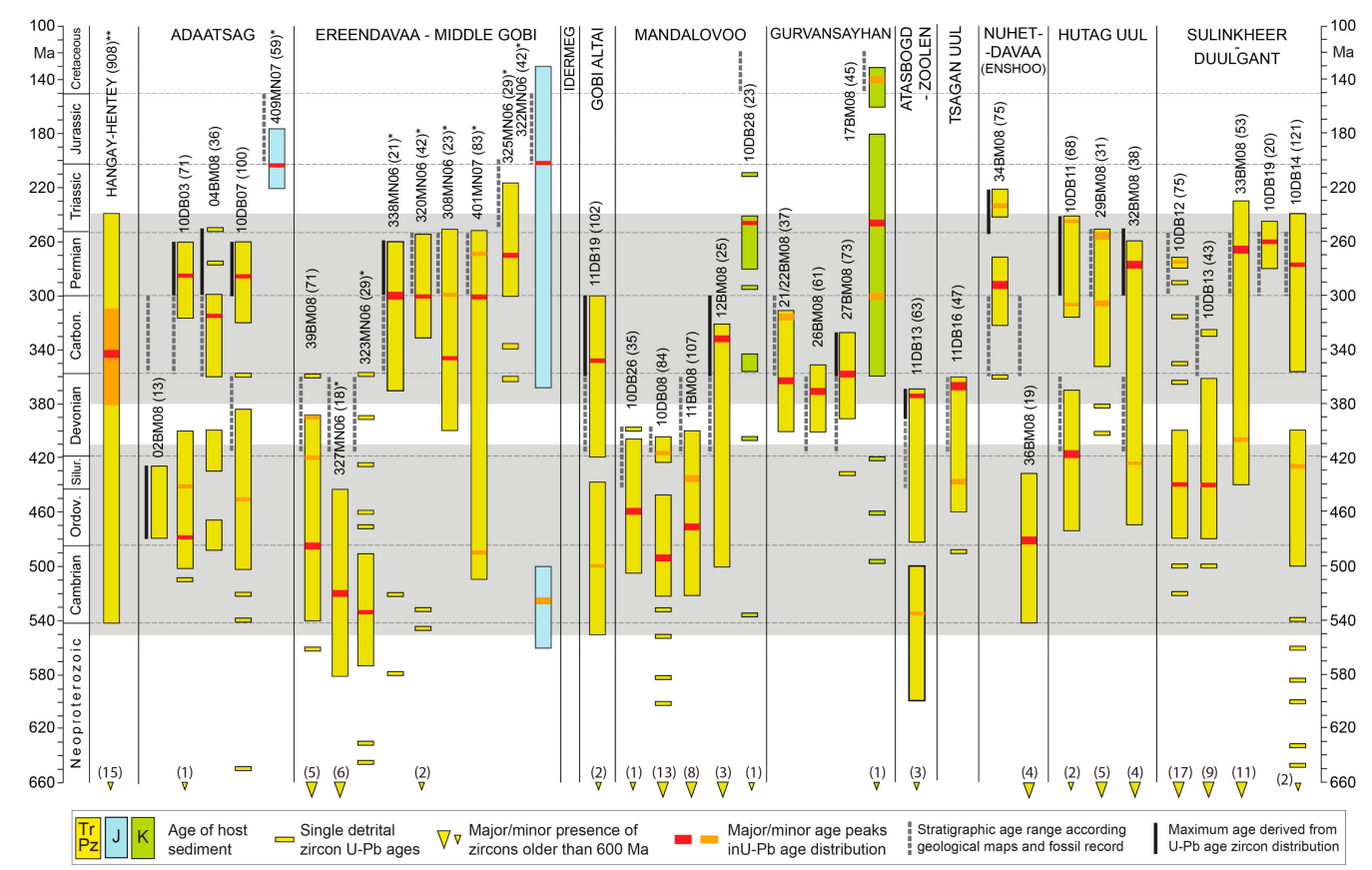

Figure 3. Summary of detrital zircon $\mathrm{U}-\mathrm{Pb}$ ages obtained from the various host sandstones and terranes (after Badarch et al. [10]). Number of grains older than $660 \mathrm{Ma}$ are also given. Time scale after Cohen et al. [50]. Note that where ages of formations indicated on maps and younger populations of detrital zircon grains do not coincide, a maximum age is inferred from the detrital zircon age data. Numbers in brackets specify how many detrital zircons were dated older than $600 \mathrm{Ma}$. * Data from Bussien et al. [24], ** denote data from Bussien et al. [24] and Ruppen et al. [31].

\subsubsection{Gurvansayhan Terrane}

This is a unique element in SE Mongolia. It comprises a varied oceanic series with pillow basalts, mélanges/olisthostromes, metamorphosed shales and sandstones, lower Silurian-lower Devonian radiolarites and Middle Devonian-Mississippian volcaniclastic sandstones and conglomerates (Figure 2E; [1,51,52]). The rock units are strongly dismembered. With Tsagaan Suvarga and Oyu Tolgoi the terrane comprises important porphyry copper mineralisation, the latter dated by Lamb and Lamb and Cox [52] and Perellò et al. [53] as Devonian. Dolgopolova et al. [48] summarised a U-Pb mean zircon peak age of $\approx 362 \mathrm{Ma}$ (Late Devonian, Famennian) from basalts, quartz monzodiorites, dacites and granodiorites. However, granitoids did dot contributed material to the presently analyzed \pm coeval sandstones because they are almost entirely free of quartz (see also below). The Carboniferous sediments unconformably overlie the folded Devonian series [54,55], and radiometric ages of post-accretionary 
dykes and intrusions suggest a collision of the oceanic arc latest in the Permian [56]. Cretaceous red beds unconformably overlap the terrane (Figures $2 \mathrm{~F}$ and 3 ).

On Chinese territory, the Gurvansayhan terrane does not appear to have a counterpart. In Mongolia, that terrane disappears along the left-lateral Zuunboyan fault or Xilin-Xiguito suture, respectively (Figure 1C) (e.g., [15]; eventually called East Gobi or Eastern Mongolian fault zone [57]), which further to the NE directly separates the Mandalovoo from the Nuhetdavaa and the Uliastai terrane, respectively.

\subsubsection{Nuhetdavaa and Enshoo Terranes}

Badarch et al. [10] classified these units as back/forearc and arc terranes, respectively. The Nuhetdavaa terrane comprises Neoproterozoic basement (gneiss, schists, marbles), Cambrian-Silurian sandstones, phyllites and shales, and conglomerates. Devonian basalts, andesites and volcaniclastic sandstones are mentioned by Badarch et al. [10]. Various Silurian to Triassic granitoids intrude the terrane.

\subsubsection{Hutag Uul Terrane}

This cratonal terrane comprises Precambrian gneiss, schists, migmatites, marble, quartz-sandstones and stromatolithic limestones. Basalts, andesites, turbiditic volcaniclastic rocks and coral-bearing limestones represent the Devonian and Carboniferous series. Badarch et al. [10] interpreted the Devonian-Carboniferous granitoid intrusion as to be related to subduction processes. Permian marine sedimentary and volcanic rocks complete the stratigraphic section (e.g., [22]).

Some terrane comparisons linked the Hutag Uul unit either with the Inner Mongolia-Jilin belt in China $[1,40]$ or the Baolidao arc-accretion complex [8], respectively. In Figure 1C, we have adapted the correlation proposed by Liu et al. [25], i.d., the Sangliao-Xilinhot block. In its Chinese occurrence, the Sangliao-Xilinhot block with Precambrian basement and Palaeozoic sandstones ( $\approx$ Silurian) was correlated with the Hutag Uul terrane by Jian et al. [58] and Xu et al. [59]. The Hutag Uul terrane is bordered in the south by the Sulinkheer-Duulgant terrane and the Solonker-Xilamalu suture.

\subsubsection{Sulinkheer-Duulgant Terrane}

It is commonly classified as an accretionary wedge unit having its eastern prolongation in the Chinese Erdaojing accretion complex (Solonker suture; [3,60]) or, respectively, with the Xar Moron-Jilin Yanji suture (e.g., [40,61], Figure 1C). According to Badarch et al. [10] and own observations the unit shows a very composite tectonic configuration, i.e., represents a large mélange body containing dismembered ophiolitic and metamorphic slivers, Carboniferous and Permian volcaniclastic and carbonate rocks. Tholeiitic pillow basalts, radiolarian cherts and limestones point to the presence of oceanic basement. A bi-modal age distribution is evident from dating a diorite at $438 \pm 4 \mathrm{Ma}$ and a gabbro at $248 \pm 2$ [12]. Some highly sheared continental basement rocks (mylonitised gneiss, amphibolite, quartzite, marble, metasandstone and argilite) occur along the northern margin of the terrane [10]. Notably, Badarch et al. [10]. mention a personal communication of L.E. Webb (1999) that the muscovite-biotite schists and mylonites revealed Ar-Ar mica ages of 271-208 Ma, which may indicate a major (Permian-Triassic) deformation event in the accretionary wedge.

\section{Materials and Methods}

\subsection{Sample Material}

We sampled and partly completed our earlier data set $[24,31]$ in the various terranes in a large section from central Mongolia to the Chinese border (Figure 1C). The location and lithologies of the samples are listed in Table 1. With respect to our data presented in Bussien et al. [24] we added four more samples in the Adaatsag and one more in the Ereendavaa terrane. All other samples from the southern terranes were collected later and represent new data sets. The collected sandstones and shales were used for petrographic analysis under the petrographic microscope and the analysis of 
detrital zircons (specifications are given in Supplementary Materials Table S1). Three samples from the Gurvansayhan terrane were derived from boreholes of the Oyu Tolgoi mining prospect $[51,54,55]$.

\subsection{Methods}

The chronostratigraphic correlation of the samples primarily follows the ages inferred on the geological map of Mongolia 1:1.5 million [47]. If the detrital zircon $\mathrm{U} / \mathrm{Pb}$ age results suggest a clearly younger age range, we suggest a "maximum sedimentation age" (Table 1, Figure 3), otherwise the detrital zircons confirmed the mapped ages.

An approximated rock composition of the detrital sources of the sandstones is evaluated by standard modal point-counts (200-400) on feldspar and carbonate stained thin-sections following grain types suggested by Folk [62] and Dickinson [63]. Because of missing age information on for example volcanic lithoclasts, this method cannot accurately provide the final plate-tectonic framework of the sampled basins. On contrary, at hands of the detrital zircon dating we partly must assume reworking of older deposits or volcanic sources into younger basins.

Zircon grains were hence isolated from crushed whole rock by hydrochloric acid $(\mathrm{HCl}, 25 \%)$ added to hydrogen peroxide $\left(\mathrm{H}_{2} \mathrm{O}_{2}\right)$. Panning, heavy liquids (bromoform), and hand picking completed the separation and allowed to obtain grains ranging from ca. $200 \mu \mathrm{m}$ to $70 \mu \mathrm{m}$. The grains were then mounted in epoxy and polished approximately at their half. Prior to isotopic analyses (U-Pb dating and Hf isotopes), all zircon grains were inspected by cathodoluminescence imaging to prove their homogeneous composition and recognize the magmatic growth by its oscillatory patterns. Only magmatic domains were analyzed and inherited cores were avoided.

$\mathrm{U}-\mathrm{Pb}$ dating was performed at the Institute of Geochemistry and Petrology ETH Zurich with a laser-ablation inductively coupled plasma mass spectrometer (Elan 6100 instrument coupled to an in-house-built $193 \mathrm{~nm}$ Excimer laser). The complex growth domains and inherited cores of the detrital zircons were avoided. A focused laser beam of 30-40 $\mu \mathrm{m}$ (depending on grain size) in diameter was applied at a pulse rate of $10 \mathrm{~Hz}$ with $0.5 \mathrm{~mJ} /$ pulse. The ablated material was carried out in helium gas $(1.1 \mathrm{~L} / \mathrm{min})$ to the spectrometer where the analytical signal was measured for 90 to $120 \mathrm{~s}$ after $30 \mathrm{~s}$ of background collection. In each analyzes, $\mathrm{Hg}^{202}, \mathrm{~Pb}^{204}, \mathrm{~Pb}^{206}, \mathrm{~Pb}^{207}, \mathrm{~Pb}^{208}, \mathrm{Th}^{232}, \mathrm{U}^{235}, \mathrm{U}^{238}$ masses were quantified sequentially. Prior and after each 15 zircons analysed we measured a set of primary and secondary standards represented by the GJ-1 zircon and the 91500Plesovice AUSZ7-5 zircon standard, respectively. Each run consisted of 3 measurement of GJ-1 to control the mass fractionation/downhole correction and one of the secondary reference materials to evaluate external reproducibility. Raw data were processed using Glitter software package (van Achtenberg et al. [64]). The Isoplot/Ex v. 4.15 [65] generated the Concordia diagrams and probability density distribution plots (divided into 25 my age bins). Repeated measurements on the Plesovice [66] give a Concordia age of $337.4 \pm 1.3 \mathrm{Ma}$, (95\% of confidence), which is identical within error to the reference value of $337.13 \pm 0.37 \mathrm{Ma}$ [67].

The in-situ Hf isotopic analyses were performed at the IGP (ETHZ, Zurich, Switzerland) using a $\mathrm{Nu}$ plasma MC-ICP-MS (Nu instrument Ltd.) coupled to an Excimer laser (GeoLas ArF, wavelength of $193 \mathrm{~nm}$ ). A spot size of $60 \mu \mathrm{m}$ in diameter was chosen to analyze already dated domains of the detrital zircon grains. The laser repetition rate was $4 \mathrm{~Hz}$ with an energy range of $10-20 \mathrm{~J} / \mathrm{cm}^{2}$. Again, helium was used as carrier gas $(0.95 \mathrm{~L} / \mathrm{min})$, and the baseline was measured within $30 \mathrm{~s}$ and analytical signal within $60 \mathrm{~s}$. Measurement of ${ }^{171} \mathrm{Yb}\left({ }^{176} \mathrm{Yb} /{ }^{171} \mathrm{Yb}=0.897145\right)$ and ${ }^{175} \mathrm{Lu}\left({ }^{176} \mathrm{Lu} /{ }^{175} \mathrm{Lu}=0.026549\right)$ allows the correction of the isobaric interference on ${ }^{176} \mathrm{Hf}$ of ${ }^{176} \mathrm{Yb}$ and ${ }^{176} \mathrm{Lu}$, respectively. Age correction to calculate initial ${ }^{176} \mathrm{Hf} /{ }^{177} \mathrm{Hf}$ ratio $(\varepsilon \mathrm{Hf}(\mathrm{t}))$ were obtained using a ${ }^{176} \mathrm{Lu}$ decay constant of $1.867 \times 10^{-11}$ year $^{-1}$, the measured ${ }^{176} \mathrm{Lu} /{ }^{177} \mathrm{Hf}$ ratio and the chondritic values of ${ }^{176} \mathrm{Hf} /{ }^{177} \mathrm{Hf}$ and ${ }^{176} \mathrm{Lu} /{ }^{177} \mathrm{Hf}(0.0332$ and 0.282772 , respectively [68]. Mud Tank and Temora zircon were used as a reference standard. The complete analytical results are provided in Supplementary Materials Tables S2-S4. 


\section{Results and Discussion}

A summary of our results is illustrated in Figure 3. Accordingly, the general pattern of major and minor peaks of detrital zircon ages in Palaeozoic sandstones records two age groups: (i) Cambrian-Silurian, and (ii) Carboniferous-Permian. Except for the Gurvansayhan, Atasbogd-Zoolen and Tsagaan Uul terranes, which show Late Devonian peaks, the basins related to the other terranes were impoverished of Devonian detrital zircon influx. Few minor Triassic peaks are observed but are more evident in Jurassic and Cretaceous post-orogenic deposits. Figure 3 also informs about the variable presence of Proterozoic basement rocks (detrital zircon ages >600 Ma) in the source terranes. The obtained data sets are provided in Supplementary Materials Tables S1 and S2.

\subsection{Adaatsag Terrane}

Detrital zircons were analysed in four new samples (Table 1, Figure 3) and are combined with three samples presented in [24]. Detrital zircon ages show that the inferred maximum ages of the sandstones and mapped ages do not concur. Although, we can refer to one Ordovician-Silurian shale (02BM08, low zircon yield because of very fine grain size) and three Permian sandstones. The modal analyses of Permian sandstones reveal an arkosic to lithic arkosic composition suggesting basement uplift detrital sources with frequent volcanic lithoclasts (Figure 4a,b,d).

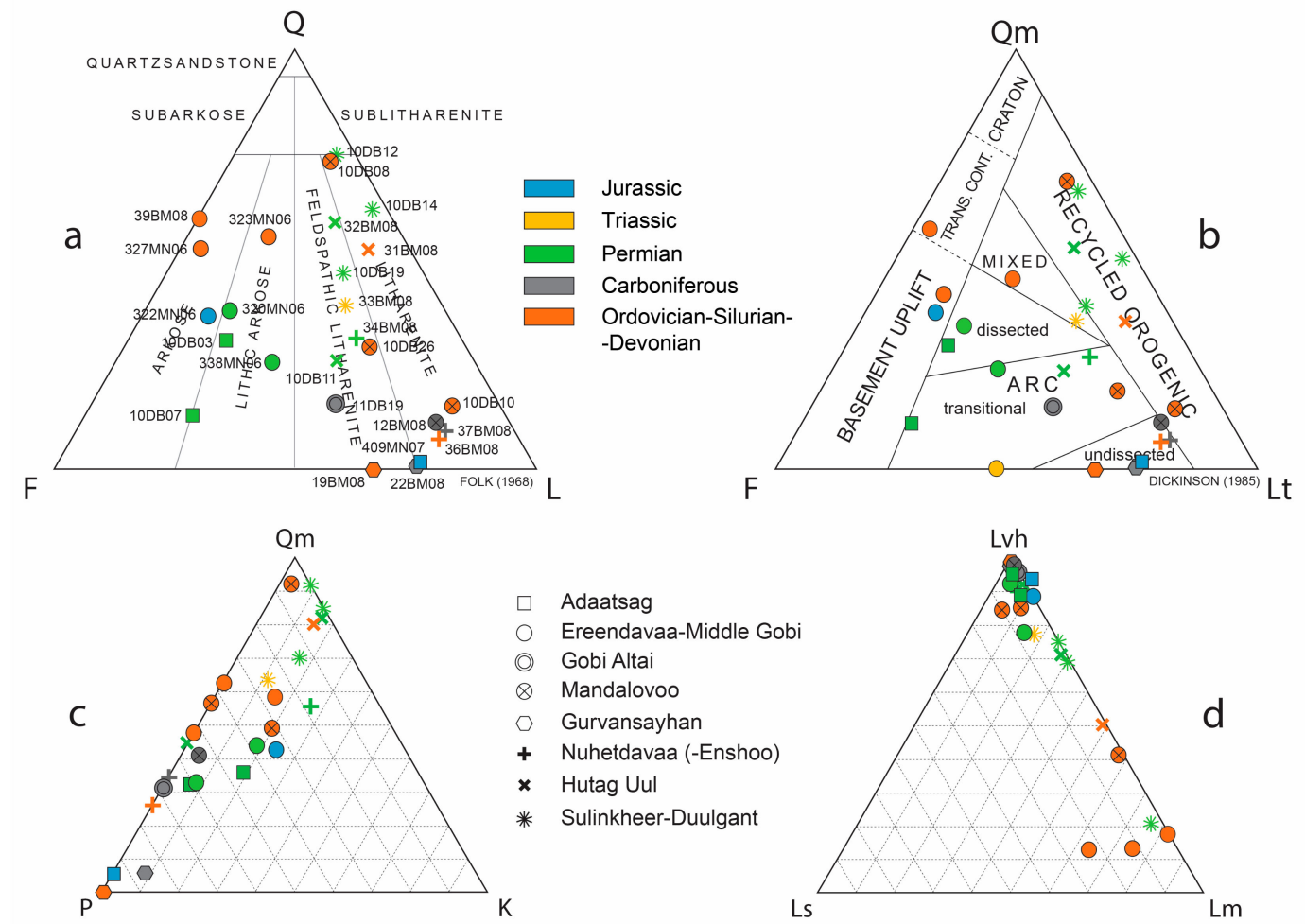

Figure 4. Detrital modes of analysed sandstones according to point-counting in ternary plots of Folk [62], (a) and Dickinson [63], (b-d) interpreting the composition and hypothetical plate tectonic position of the detrital sources. Abbreviation code: $Q$, total quartz; F, feldspar; L, lithoclasts; Qm, monocrystalline quartz; Lt, total lithoclasts (including quartzeous aphanitic ones); P, plagioclase; K, K-feldspar; Lvh, volcanic-hypabbyssal lithoclasts; Ls, sedimentary lithoclasts; Lm, metamorphic lithoclasts. 
As already observed by Bussien et al. [24], zircons older than $660 \mathrm{Ma}$ (Cryogenian and older) are extremely rare (Figure 5). Regarding the detrital zircon age distribution, we observe that the mostly Permian sandstones also provide insight to the earlier history of the involved source areas (due to cannibalism). Therefore, we observe two main age clusters spanning the Ordovician-Silurian and Carboniferous-Permian (Figure 5a). The new analyses here available emphasise the strong Ordovician-Silurian population. Time corrected Epsilon $\mathrm{Hf}(\mathrm{t})$ ratios $\left(\varepsilon \mathrm{Hf}_{(\mathrm{t})}\right)$ show most detrital zircons to have been derived from moderately juvenile to juvenile melts. Including the negative ones and that along the CHUR, we discern a slight positive $\varepsilon \mathrm{Hf}_{(\mathrm{t})}$ trend in time.

It is to note, the Adaatsag terrane is an ophiolitic suture zone comprising mélanges. By definition, suture zones may contain blocks and clastic formations, which were derived from both margins of a closing oceanic domain (polygenic mélanges sensu Raymond, [69]). The detrital zircon age and Hf-isotope results of Bussien et al. [24] and the present study stem from Permian-Jurassic maximum age sandstones deposited during early stages and during collision of the Hangay-Hentey and Ereendavaa margins of the Mongol-Okhotsk Belt, and therefore, we are not able to discriminate in detail the detrital input from the involved margins. However, the analysed Permian sandstones represent early collisional sandstones, because they are tectonically deformed in east-west striking belts (Figure 2A). Considering the well pronounced Ordovician-Silurian detrital zircon age population and related positive $\varepsilon \mathrm{Hf}_{(t)}$ values, a strong similarity with results from the Hangay-Hentey terrane appears evident (Figures $4 \mathrm{a}$ and $5 \mathrm{~h}$ ). Therefore, a predominant detrital supply from the northern convergent margin (in modern coordinates) of the Mongol-Okhotsk Ocean is probable.

\subsection{Ereendavaa-Kherlen-Idermeg Terrane Group and Middle Gobi Belt}

For these terranes (called Ereendavaa-Middle Gobi for simplicity) we use mostly the data set of Bussien et al. [24] and an additional new one (39BM08) (Table 1). According to detrital zircon dating the analysed sandstones are of Ordovician to Jurassic maximum age (Figure 3). The Ordovician, Devonian and Permian-Early Triassic sandstones reveal a quartz-rich $(\geq 50 \%)$ arkosic composition, which correlates approximately with continental basement sources (Figure 4).

The Silurian-Ordovician and Devonian sandstones likewise reveal scattered occurrence of detrital zircons older than $660 \mathrm{Ma}$. The Ereendavaa-Middle Gobi terrane records two main detrital zircon age clusters spanning the Late Neoproterozoic-Silurian, and the Carboniferous-Permian. While the former is characterised mostly by negative and transitional $\varepsilon \mathrm{Hf}_{(\mathrm{t})}$ numbers, the latter shows positive ones in the range of +5 to +15 (Figure $5 b$ ). The Jurassic sandstone, unconformably topping the terrane, matches a similar trend, i.e., further reworking of similar source rocks into the Jurassic continental basin. Comparably to the Adaatsag samples, Devonian detrital zircons are rare again.

The trend depicted by the $\varepsilon \mathrm{Hf}_{(t)}$ ratios infers a transition from evolved to moderately juvenile/juvenile magma sources, in which the zircons crystallised. This can be correlated with the change from extension-related (comprising a prasinitic sill; Figure 2C) to subduction-related volcano-plutonic activity in the Carboniferous (as suggested by Bussien et al. [24]) along the southern margin of the Mongol-Okhotsk Ocean. Some exceeding $\varepsilon \mathrm{Hf}_{(t)}$ points of +10 to +20 in the age range of 500-380 Ma may suggest a connection with and transport from the adjacent Mandalovoo terrane to the south, where subduction occurred at that time (see Figures $4 \mathrm{~b}$ and $5 \mathrm{c}$ ). 

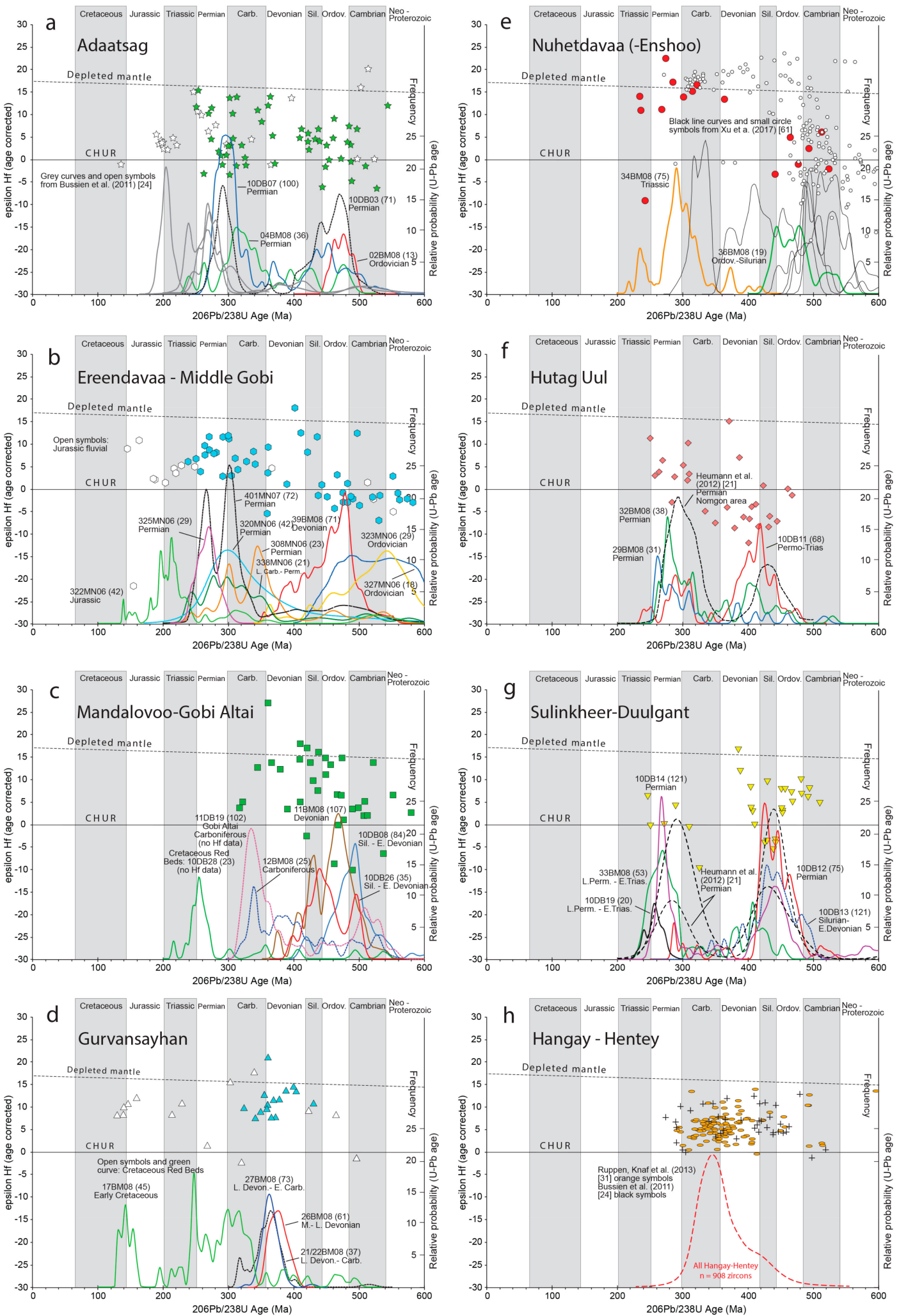

Figure 5. U-Pb detrital zircon age populations represented by relative probability curves plotted against age corrected epsilon Hafnium-isotope ratios as derived from sandstones in various terranes. The stratigraphic sample ages are indicated according to mapped ages or sample maximum age from detrital zircons presently analysed (see Table 1). Numbers in brackets after the sample numbers indicate the the number of detrital zircons analysed. 


\subsection{Mandalovoo-Gobi Altai Terranes}

According to the obtained maximum detrital zircon ages, Silurian-Devonian and Carboniferous sandstones were analysed (Figures 3 and 5). They show a feldspatic litharenite and litharenite composition rich in volcanic clasts (Figure $4 \mathrm{~d}$ ). A sourcing in volcanic arc and recycled orogenic rock units can be inferred (Figure 4 b). In the detrital zircon age distribution two major clusters are identified overlapping with the Cambrian to Silurian and Carboniferous periods. Again, Devonian ages appear subordinate (Figures 3 and $4 \mathrm{c}$ ). Except for a few negative ones, $\varepsilon \mathrm{Hf}_{(\mathrm{t})}$ values mainly plot in the moderately juvenile to depleted mantle source fields (Figure 5c).

The hafnium-isotope characteristics of the Mandalovoo terrane detrital zircons suggest a subduction-related volcano-plutonic source of the sandstone deposits active from at least later Cambrian until the Carboniferous. The positive trend in time suggests a successive depletion trend of the zircon source magmas. Younger sediments, except the discordantly overlying Cretaceous red beds of the Flaming Cliffs, we have not identified. These record reworking of Permian/Triassic detrital zircons as commonly observed (Figure 5c). According to Badarch et al. [10] the deformed rock series of the Mandalovoo terrane is unconformably overlain by Permian and Cretaceous clastic formations. Our finding of Silurian to Carboniferous maximum ages of the sandstones confirms this and suggests that the Mandalovoo depositional site was tectonically eliminated at the Carboniferous/Permian transition. The facies association comprising pelagic/turbiditic, shallow water limestones and continental alluvial fan deposits (Figure 2D) suggests that the terrane formed in a shallowing-upward forearc-accretionary wedge environment.

\subsection{Gurvansayhan Terrane}

Two representative sandstone samples were point-counted for their modal composition. They are very rich in volcanic lithoclasts and fall in the feldspatic litharenite and litharenite fields, virtually free of detrital quartz (Figure 4). An undissected volcanic arc source [63] is implied. In spite of the basic to intermediate chemistry of the supplying source, we were successful to obtain a reasonable number of detrital zircons which ages span the Devonian and Carboniferous (Figures 3 and 5d). Peak ages lie concurrently on the Devonian-Carboniferous transition. This compares well with the U-Pb average detrital zircon peak age of $\approx 362 \mathrm{Ma}$ obtained by Dolgopolova et al. [48]. Older zircons from continental basement completely lack. The volcaniclastic facies and facies associations we studied in the Oyu Tolgoi mining district, the absence of continental influx to the basin and the confined detrital zircon age distributions corroborate an intra-oceanic arc environment [56], which soon after its construction was eliminated by tectonic processes.

The $\varepsilon \mathrm{Hf}_{(\mathrm{t})}$ results from the discordantly overlying, post-collisional continental red beds document that moderate juvenile and juvenile volcano-plutonic sources continued activity during Mesozoic until Early Cretaceous [70,71]. The $160-120$ Ma detrital zircon age data we obtained match the regionally occurring surficial volcanic activity, which was sourced in a metasomatized depleted lithospheric mantle with minor crustal contamination $[70,71]$. Other older detrital zircon ages presumably were reworked from the short-lived Gurvansayhan intra-oceanic arc.

\subsection{Nuhetdavaa (-Enshoo) Terrane}

The area occupied by the Enshoo terrane is very narrow and characterised by poor outcrop conditions in Mongolia. According to Badarch et al. [10], the Nuhetdavaa terrane is classified as back or forearc basin and an island arc (Enshoo), respectively. We assume their common relationship and consider our results from Nuhetdavaa as also applying to the Enshoo unit. Following the maximum age attributions by our detrital zircon dating, the mapped ages are quite different (Table 1). We present results from an Ordovician, a Permian-Triassic, and a not age-confirmed (detrital zircons) Carboniferous sandstone (Figures 4 and 5e). 
Petrographically, the two older sandstones (Ordovician and Carboniferous) are litharenites poor in quartz ( $\leq 10 \%)$, the Permian-Triassic one contains $\approx 40 \%$ of that grains. The former two plot in the undissected volcanic arc, and the latter almost in the recycled orogenic field (Figure 4). The Ordovician sandstone reveals $\varepsilon \mathrm{Hf}_{(\mathrm{t})}$ values transitional along the CHUR line (ca. -3 to +8 ), which may indicate a crustal contaminated continental volcanic arc source input. The Permian-Triassic sandstone shows a main influx of later Carboniferous to Permian zircons derived from juvenile to depleted mantle volcano-plutonic sources. No older grains than Cambrian became obvious from our data.

Another analysis of detrital zircons in the north eastern extension of the Nuhetdavaa terrane on Chinese territory (Uliastai continental margin, Figure 1) is available from $\mathrm{Xu}$ et al. [42]. Therein, Ordovician-Devonian sandstones record Neo-Proterozoic to Cambrian sources with a large spread of $\varepsilon \mathrm{Hf}_{(\mathrm{t})}$ from -10 to +20 . This is interpreted by the authors to show derivation of the sands from mixed sources in their Northern accretionary orogen (Hutag Uul terrane in our terminology). The detrital zircon age data and Hafnium-isotope signatures of $\mathrm{Xu}$ et al. [42], and our results firstly corroborate the correlation of the Nuhetdavaa terrane with the Uliastai terrane in the Xing'an block. Secondly, the time trend depicted by the $\varepsilon \mathrm{Hf}_{(\mathrm{t})}$ signatures suggests a Neo-Proterozoic rift/passive margin tectonic environment which inverted from about late Cambrian to a subduction related continental margin.

\subsection{Hutag Uul Terrane}

From this terrane we can present detrital zircon results from three samples correlatable with Permian and Permo-Triassic maximum ages (Table 1, Figure 3). Modal analysis of two sandstones classify them as feldspathic litharenites and litharenites and plot in the transitional arc and recycled orogenic fields (Figure 4). The zircon yield showed to be moderate but two age clusters appear consistent, Silurian-Middle Devonian and Pennsylvanian-Permian (Figure 5f). These two populations reveal very distinct hafnium-isotope ratios. The older one mostly has negative $\varepsilon \mathrm{Hf}_{(t)}$ values down to -15 , the younger one positive up to +10 . Consequently, the Silurian-Middle Devonian zircons crystallised in crust-derived magmas, the Pennsylvanian-Permian ones in moderately juvenile and juvenile magmas, significant for crustal contamination of rising mantle magmas.

In plate-tectonic terms, the Hutag Uul continental (block) terrane [10] first experienced extension (rifting) during Silurian-Middle Devonian. It was inverted to a subduction regime environment with the establishment of a continental margin arc from about Pennsylvanian (late Carboniferous) on. Due to similar Permian-Triassic detrital zircon age distributions sandstones (Figure 5e,f), a common detrital source in the Nuhetdavaa continental margin arc may have existed.

Because of possible affinity of the Atasbogd/Zoolen and Tsagaan Uul terranes with such in south eastern Mongolia like Hutag Uul or Nuhetdavaa-Enshoo, some preliminary detrital zircon age dating on two Late Devonian sandstones are provided (Figure 3). Both, by revealing major Devonian peaks most likely cannot be correlated with the Hutag Uul and other terranes in the South Mongolian belt south of the MML. A common genesis with sandstones of the same age in Gurvansayhan terrane is impossible according to our sandstone framework data (Figure 4).

\subsection{Sulinkheer-Duulgant Terrane}

From this terrane (elsewhere also called Solonker multiple suture; e.g., [3,9]) a large data set is available, however, mostly from Permian sandstones (Figures 3 and 5). The point-counted Permian-Early Triassic sandstones have a feldspathic litharenite and litharenite composition quite rich in quartz grains $(\approx 50-75 \%)$. The detrital source from a recycled orogen is inferred (Figure 4$)$. With regard to the detrital zircon ages and $\varepsilon \mathrm{Hf}_{(\mathrm{t})}$ measurements (Figure $5 \mathrm{~g}$ ), again a distinct bi-modal age distribution is observed: (i) an older population overlapping with later Cambrian and Early Devonian with major peaks in Ordovician and Silurian; the $\varepsilon \mathrm{Hf}_{(t)}$ values are mostly positive up to +20 , but a certain crustal contamination of the magmas seems also displayed, (ii) the younger one correlates with the Permian to Early Triassic. Less supported by the number of $\varepsilon \mathrm{Hf}_{(\mathrm{t})}$ data points, a magma source of the detrital zircon with crustal contamination may be assumed. An identical bi-modal age distribution 
was reported by Heumann et al. [21] in Permian deposits in the Nomgon area of that terrane (peaks at $\approx 300$ and $450 \mathrm{Ma}$, respectively). All Permian sample spots showed tectonic tilting to vertical bedding documenting post-depositional deformation.

\subsection{Hangay-Hentey Terrane}

In earlier project work we investigated the Mongol-Okhotsk Belt on the Mongolian territory [24,31]. The Hangay-Hentey accretionary complex comprises lithologic elements as oceanic basalts, seamount capped by crinoidal limestones, pelagic radiolarites, shales and turbiditic fan and forearc deposits [24,31,72,73]. Litho-, chrono- and biostratigraphic results clearly indicate that the Mongol-Okhotsk Ocean opened in Silurian. In summary, the Hangay-Hentey terrane represents the accretionary wedge and forearc that formed along the northern margin of the Mongol-Okhotsk Ocean. Detrital zircon age and hafnium-isotope signatures (Figure 5h) document continuous clastic influx from mainly moderately evolved volcano-plutonic continental arc source rocks [23,30], from Silurian until Permian.

With regard to our results, there are two points to emphasise: (i) also the analysed Permian sandstones give a precise insight into the earlier history of the terrane, i.e., no earlier collision has modified the supplying source rock composition, (ii) the rifting and opening of the Mongol-Okhotsk Ocean in Silurian is obviously not characterized by negative $\varepsilon \mathrm{Hf}_{(\mathrm{t})}$ values of Silurian zircons as it would be expected. In view of the large number of zircons that have been reliably dated, we do not assume that the Hf values were biased by incorrect age attributions [74]. Presumably, the chemical signature of the newly produced magmatism was inherited from repeated earlier orogenic processes. In other words, the magmatic melts formed in a formerly (Cambrian) homogenised crust.

\section{Palaeotectonic Evolution}

\subsection{General Trends}

To distinguish between extensive and compressive plate tectonic processes we base our interpretations mainly on the age populations and related $\varepsilon \mathrm{Hf}_{(\mathrm{t})}$ signatures of the detrital zircons in sandstones. Interestingly, it also turns out that the measured age populations in younger formations (e.g., Permian) provide insight into earlier paleotectonic events through the recycling of older formations.

From the overview of the detrital zircon ages (Figure 3) in the different terranes in the Central and South Mongolian belts it becomes evident that major magmatic (volcanic) activity took place in two periods, from Cambrian to Silurian and from Late Devonian to Permian, respectively. We identify two exceptions: (i) in the Gurvansayhan of Oyu Tolgoi detrital zircon ages are limited in majority to Late Devonian and less to Carboniferous, and (ii) in the Hangay-Heney basin Late Devonian to Carboniferous detrital zircon influx prevailed. Hence, this points to their distinctive geological development compared to the other terranes, because in the latter deficits of Devonian zircons are discerned (Figures 3 and 5). Another point to note is that our few data from the Zoolen and Tsaagan Uul terranes indicate that they seemingly cannot be correlated with any formations east of the Gurvansayhan terrane.

\subsection{Development in Time}

\subsubsection{Late Cambrian-Silurian}

According to our results, in the late Cambrian we are able to distinguish two composite continental blocks along and within the Palaeo-Asian Ocean (Figure 6) which were separated by the Ondor Sum Ocean as described in NW China (e.g., Miao et al. [12]; Wilhem et al. [6]): (i) to the north the Late Cambrian collage (A in Figure 6) comprising the amalgamated Baikalids (e.g., [14,75]) with the later Hangay-Hentey, Ereendavaa, Idermeg, Gobi Altai and Mandalovoo terranes, and the Kherlen 
oceanic suture (Miao et al. 2016); (ii) in the south a composite continental block including the later Nuhetdavaa-Enshoo, Hutag Uul and Sulinkheer-Duulgant terranes bordered by the Solonker.

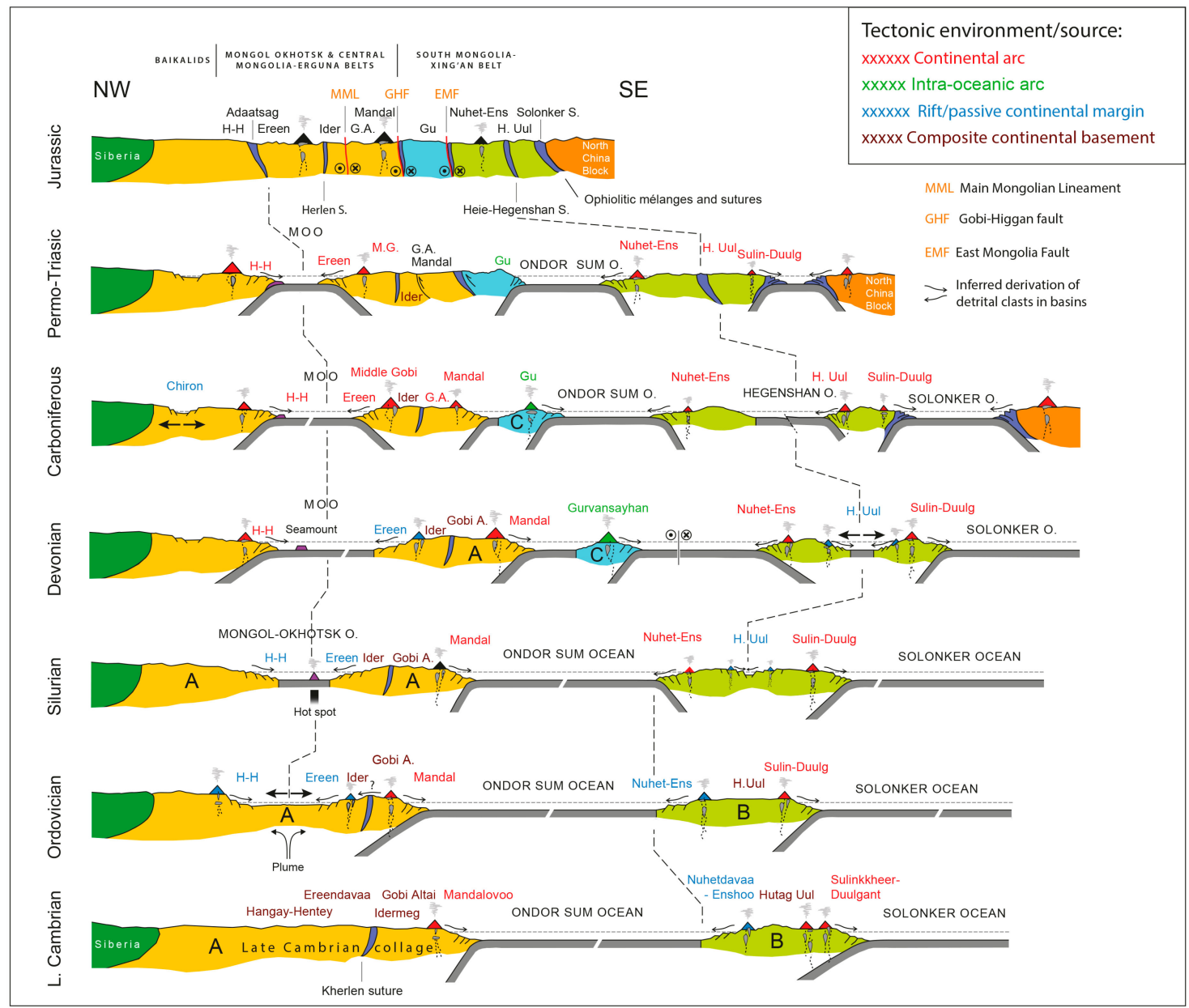

Figure 6. Palaeotectonic development of the Central Asian Orogenic Belt in Mongolia (oriented $\approx \mathrm{N}-\mathrm{S}$ in modern coordinates) in geologic time from late Cambrian to Jurassic. The inferred plate tectonic environment of terranes and sources are highlighted in colour. Central Mongolian Superterrane, A; Southeastern Mongolian Superterrane, B; Gurvansayhan Terrane, C.

Ocean in the south (B in Figure 6). The Solonker Ocean belongs to the Palaeo-Asian Ocean situated between our block B and the North China Block.

Subduction took place at the southern edges of both blocks as the ages of the detrital zircon $S$ and the mostly positive $\varepsilon \mathrm{Hf}_{(\mathrm{t})}$ signatures (Figure $5 \mathrm{c}, \mathrm{g}$ ) in the Mandalovoo-Gobi Altai and Sulinkheer-Duulgant terranes infer. The two continental margins developed through the northward subduction of the Ondor Sum and Solonker oceans, respectively. Mixed mantle and crust generated magmas were produced in the sourcing continental volcanic arcs. Both units have in common that the volcanic influx decreased during Devonian most likely due to decelerated subduction. This coincides with the Gurvansayhan intra-oceanic arc generation and the initiation of subduction along the northern Mongol-Okhotsk Ocean (Figure 6; see also below). The mostly recycled orogenic source signature in Permian-Triassic sandstones in the Sulinkheer-Duulgant terrane (Figure $4 \mathrm{~b}$ ) reveal important presence of crustal rocks in the arc at that time. Mandalovoo-Gobi Altai Palaeozoic sandstones reflect a higher contribution of contemporaneous influx from the volcanic continental arc.

In the Nuhetdavaa (-Enshoo) terrane our sparse data are well completed by that of Xu et al. [43] in the comparable Uliastai passive margin terrane in Inner Mongolia. Negative and intermediate 
$\varepsilon \mathrm{Hf}_{(\mathrm{t})}$ values (Figure 5e) suggest crustal derived magmatic-volcanic activity in a passive margin setting. However, it will be inverted later (see below).

Epsilon Hf ratios suggest that in the late Cambrian collage, during Ordovician-Silurian the composite continental block, including the Hangay-Hentey, Ereendavaa and Idermeg terranes experienced rifting, extension and generation of oceanic lithosphere of the Mongol-Okhotsk Ocean in Silurian $[24,27]$. In the later Hangay-Hentey accretionary wedge terrane, the timing is well supported by biostratigraphic dating and seamount stratigraphy [31,72,73]. Along the southern margin of the Mongol-Okhotsk Ocean, in the Ereendava terrane, extension in a passive margin situation is suggested by a monotonous turbiditic facies association (including prasinitic dykes) and negative $\varepsilon \mathrm{Hf}_{(\mathrm{t})}$ values. The spreading may have been driven by a mantle plume (Figure 6) rising from the mantle transition zone. Such process commonly is associated with hot-spot generation [47].

During Silurian the Mongol-Okhotsk Ocean oceanic lithosphere was created bearing a prominent volcanic seamount capped by crinoidal limestones which became progressively drowned and covered by pelagic and turbiditic deposits [31]. The highly negative $\varepsilon \mathrm{Hf}_{(\mathrm{t})}$ signatures in detrital zircons detected by $\mathrm{Xu}$ et al. [43] and our measurements suggests the Nuhetdavaa (-Enshoo) and Uliastai passive margins to have been inverted to a continental arc regime during Silurian by the southward subduction of the Ondor Sum Ocean (Figure 6).

\subsubsection{Devonian-Carboniferous}

The Devonian period brought about great changes in the paleotectonic development of the Palaeo-Asian Ocean. Viewed from north to south these were: (i) start of northward subduction of the Mongol-Okhotsk Ocean under the Baikalids (see also [14,24,31]), (ii) the establishment of the intra-oceanic Gurvansayhan island arc in the Ondor Sum Ocean by north-dipping intra-oceanic subduction [6,53], and (iii) the opening of the Hegenshan Ocean [12]. The latter was preceded by the Silurian rifting in the Hutag Uul area.

In the Carboniferous period the southern passive margin of the Mongol-Okhotsk Ocean (Ereendavaa terrane) switched to subduction of the Mongol-Okhotsk Ocean with the establishment of a continental arc [24]. Medium positive $\varepsilon \mathrm{Hf}_{(\mathrm{t})}$ rates (Figure $5 \mathrm{~b}$ ) suggest a mixed mantle-crust source of the melts. Similar $\varepsilon \mathrm{Hf}_{(\mathrm{t})}$ signatures (0 to 15$)$ of detrital zircons are observed in Hangay-Hentey sandstones (Figure $5 \mathrm{~h}$ ) which corroborates their common beginning in the late Cambrian collage. In the Hutag Uul terrane the $\varepsilon \mathrm{Hf}_{(\mathrm{t})}$ data show a trend to positive values during the transition from Devonian to Carboniferous. This suggests that the former passive continental margin has been inverted into a subduction-linked one. The newly emerging continental volcanic arc obviously is continued in the Sunid-Baolidao volcanic arc in Inner Mongolia [2,9,12].

\subsubsection{Permian-Triassic}

The Permo-Triassic time was characterized by the elimination of several oceanic domains, and the collision of volcanic arcs as the youngest ages of the detrital zircons suggest (Figures 5 and 6). Due to the obtained minimum Carboniferous ages of the detrital zircons in both terranes, the Gurvansayhan intra-oceanic volcanic arc and the Gobi Altai-Mandalovoo continental island arc appear to have collided with the Idermeg continental sliver in the Permian. Cretaceous continental red beds overlay these terranes with unconformity. They partly show the reworking of older Palaeozoic material (Figure $5 c, d$ ) and distinct peaks at the Permian-Triassic transition. Probably this material was supplied from the still active Ereendavaa-Middle Gobi continental volcanic arc to the north. In the Baikalid realm, since the Devonian the northward subduction of the Mongol-Okhotsk Ocean has driven back-arc extension and mixed continental-marine sedimentation (e.g., Chiron basin; Popeko et al. [75]). Minor occurrence of Triassic detrital zircons in sandstones of the Hangay-Hentey, Ereendavaa-Middle Gobi, Nuhetdavaa (-Enshoo), Hutag Uul and Sulinkheer-Duulgant domains (Figure 3) attest their continued magmatic and sedimentary activity during the Permian and Triassic period. 


\subsubsection{Jurassic}

The closure of the Mongol-Okhotsk Ocean and collision of the Hangay-Hentey accretionary complex with the Ereendavaa margin is timely constrained by generally flat-lying Jurassic continental sandstones and conglomerates, which unconformably cover deformed older series [22,24]. Both analysed Jurassic sandstones show peak detrital zircon ages at the Triassic-Jurassic transition (Figure 3). According to our variable age and Hf-isotope results (Figure 5a) from the Adaatsag suture, we infer that detrital debris from both margins was reworked into the analysed, tectonically deformed Permian-Triassic sediment series. Consequently, the final closure of the Mongol-Okhotsk Ocean was acquired at the Triassic-Jurassic transition (see also [44]). However, in other places (Noyon Uul area) Dimitru and Hendrix [76] documented continued collisional deformation and exhumation of Jurassic deposits. Our results from the southern realms (Nuhetdavaa-Enshoo, Hutag Uul and Sulinkheer-Duulgant) record youngest detrital zircons in majority of Permian and minor Triassic age. This explains the Late Triassic elimination of sedimentation sites associated with the consumption of the Ondor Sum and Solonker oceans as earlier suggested by e.g., [5,9,11]. Finally, the Jurassic closure of the Palaeo-Asian Ocean and collision of the terranes produced a peneplain surface, which stayed passive for about $150 \mathrm{My}$ [77].

\subsubsection{Terrane Accretion in Relationship with Siberian Rotation}

In spite of the well documented clock-wise rotation of the Siberian cratonal core of the Central Asian Orogenic Belt $[9,10]$, it is difficult to perceive the movements of the individual terranes. According to our results, the Central Mongolia-Erguna belt terranes (Gobi Altai, Mandalovoo and the Gurvansayhan) were welded to Siberia at the transition of late Carboniferous to Early Permian (Figure 6). They should have experienced similar rotation with Siberia from the late Carboniferous until end-Permian (e.g., [9,10]). For constraining the end of rotation, the results of Lehmann et al. [19] may be useful. According to the structural analysis of these authors, in southwestern Mongolia all terranes including the Baydrag block underwent $\mathrm{S}-\mathrm{N}$ oriented tectonic shortening from ca. mid-Permian to Late Triassic. This means the southern South Mongolia-Xing'an and Inner Mongolia-Xilin Belts could have reached their position in the Jurassic without experiencing rotation. Later, during Jurassic and Cretaceous important coulissage of terranes along preferentially left-lateral fault zones and sutures in the range of tens to hundred kilometers occurred (e.g., $[17,76,78])$.

\section{Conclusions}

The present data set proves that detrital zircon age and Hf-isotope signatures strongly support provenance analysis aimed at reconstructing palaeogeographic and -tectonic processes in orogenic belts, and particularly in the Central Asian Orogenic Belt. Notably, the detrital zircon results from pre-collisional sandstone formations (Permian-Triassic) partly open a window on palaeotectonic processes even far in the past, because most larger blocks remained isolated during their history. Based on earlier terrane subdivisions in central and southern Mongolia we infer a new, clearer terrane subdivision by assembling smaller, genetically related terranes in larger superterranes.

A key element for the plate-tectonic reconstruction is the Gurvansayhan terrane. By its clear intra-oceanic setting, the division into a northern superterrane analogous with the Mongol-Okhotsk Belt and the Central Mongolia-Erguna Belt and a southern superterrane analogous with the South Mongolia-Xing' an and Inner Mongolia-Jilin belts) is acceptable (Figure 6). However, it persists an open question if and where the Gurvansayhan terrane can be traced into NW China.

These superterranes depict different tectonic and sedimentary evolutions in time and space. Each superterrane represents a plate tectonic assemblage of continental basement slivers, continental arc, forearc and backarc elements. However, there is no age or facies parallelism or repetition across the entire belt obvious, which would support doubling of terranes by oroclinal bending as supposed earlier (e.g., [33]). 
Over-all terranes and time (late Cambrian-Cretaceous), the $\varepsilon \mathrm{Hf}_{(\mathrm{t})}$ values show a trend towards positive numbers (see Supplementary Materials file). This suggests progressive removal of old crust and lithospheric mantle with increasing contribution of juvenile crust to magma reservoirs [79].

Supplementary Materials: The following are available online at http://www.mdpi.com/2075-163X/10/10/880/s1, Table S1: Table 1 extended providing informations on DGM sample positions, Table S2: All Terranes U-Pb and eHf LA-ICP-MS results, Table S3: LA-ICP-MS U-Pb detrital zircon ages of Bussien et al. 2011, Table S4: LA-ICP-MS eHf data of Bussien et al. 2011.

Author Contributions: W.W. and A.v.Q. were responsible for the project and participated with D.B., M.B. and C.A. in the fieldwork and the selection of the sample material. C.A. and M.B. contributed by their experience and knowledge of the geology of Mongolia. D.B. and M.B. carried out the various analyses in the laboratories of the Department of Earth Sciences ETH Zurich under the advice of A.v.Q. and W.W. All authors contributed to the design of the submitted manuscript. All authors have read and agreed to the published version of the manuscript.

Funding: This research was supported by Swiss Science Foundation grants 2-77927-06 and 2-77047-11 and ETH Zurich internal support.

Acknowledgments: We appreciate David Crane and Imants Kavalieris (Ivanhoe Corp.) for introduction and for providing borehole data and samples from the Oyu Tolgoi mining project. This project was fully supported by Swiss Science Foundation grants 2-77927-6 and 2-77047-11. We would like to thank three anonymous reviewers for constructive suggestions to improve the earlier versions of the manuscript.

Conflicts of Interest: The funders had no role in the design of the study; in the collection, analyses, or interpretation of data; in the writing of the manuscript, or in the decision to publish the results.

\section{References}

1. Zorin, Y.A.; Zorina, L.D.; Spiridonov, A.M.; Rutshtein, I.G. Geodynamic Setting of Gold Deposits in Eastern and Central Trans-Baikal (Chita Region, Russia). Ore Geol. Rev. 2001, 17, 215-232. [CrossRef]

2. Xiao, W.; Windley, B.F.; Hao, J.; Zhai, M. Accretion Leading to Collision and the Permian Solonker Suture, Inner Mongolia, China: Termination of the Central Asian Orogenic Belt. Tectonics 2003, 22. [CrossRef]

3. Jahn, B.-M.; Capdevila, R.; Liu, D.; Vernon, A.; Badarch, G. Sources of Phanerozoic granitoids in the transect Bayanhongor-Ulaan Baatar, Mongolia: Geochemical and Nd isotopic evidence, and implications for Phanerozoic crustal growth. J. Asian Earth Sci. 2004, 23, 629-653. [CrossRef]

4. Windley, B.F.; Alexeiev, D.; Xiao, W.; Kröner, A.; Badarch, G. Tectonic Models for Accretion of the Central Asian Orogenic Belt. J. Geol. Soc. 2007, 164, 31-47. [CrossRef]

5. Kröner, A.; Windley, B.F.; Badarch, G.; Tomurtogoo, O.; Hegner, E.; Jahn, B.M.; Gruschka, S.; Khain, E.V.; Demoux, A.; Wingate, M.T.D. Accretionary Growth and Crust Formation in the Central Asian Orogenic Belt and Comparison with the Arabian-Nubian Shield. Mem. Geol. Soc. Am. 2007, 200, 181-209. [CrossRef]

6. Wilhem, C.; Windley, B.F.; Stampfli, G.M. The Altaids of Central Asia: A Tectonic and Evolutionary Innovative Review. Earth Sci. Rev. 2012, 113, 303-341. [CrossRef]

7. Li, S.; Wang, T.; Wilde, S.A.; Tong, Y. Evolution, Source and Tectonic Significance of Early Mesozoic Granitoid Magmatism in the Central Asian Orogenic Belt (Central Segment). Earth Sci. Rev. 2013, 126, 206-234. [CrossRef]

8. Xiao, W.; Windley, B.F.; Sun, S.; Li, J.; Huang, B.; Han, C.; Yuan, C.; Sun, M.; Chen, H. A Tale of Amalgamation of Three Permo-Triassic Collage Systems in Central Asia: Oroclines, Sutures, and Terminal Accretion. Annu. Rev. Earth Planet. Sci. 2015, 43, 477-507. [CrossRef]

9. Cocks, L.R.M.; Torsvik, T.H. Siberia, the Wandering Northern Terrane, and Its Changing Geography through the Palaeozoic. Earth Sci. Rev. 2007, 82, 29-74. [CrossRef]

10. Badarch, G.; Cunningham, W.D.; Windley, B.F. A New Terrane Subdivision for Mongolia: Implications for the Phanerozoic Crustal Growth of Central Asia. J. Asian Earth Sci. 2002, 21, 87-110. [CrossRef]

11. Miao, L.; Zhu, M.; Liu, C.; Baatar, M.; Anaad, C.; Yang, S.; Li, X. Detrital-zircon age spectra of Neoproterozoic-Paleozoic sedimentary rocks on the Ereendavaa terrane in NE Mongolia: Implications for the early-stage evolution of the Ereendavaa terrane and the Mongol-Okhotsk ocean. Minerals 2020, 10, 742. [CrossRef]

12. Miao, L.; Zhang, F.; Fan, W.M.; Liu, D. Phanerozoic Evolution of the Inner Mongolia-Daxinganling Orogenic Belt in North China: Constraints from Geochronology of Ophiolites and Associated Formations. Geol. Soc. Am. Spec. Publ. 2007, 280, 223-237. [CrossRef] 
13. Donskaya, T.V.; Gladkochub, D.P.; Mazukabzov, A.M.; Ivanov, A.V. Late Paleozoic-Mesozoic Subduction-Related Magmatism at the Southern Margin of the Siberian Continent and the 150 Million-Year History of the Mongol-Okhotsk Ocean. J. Asian Earth Sci. 2013, 62, 79-97. [CrossRef]

14. Porter, T.M. The Geology, Structure and Mineralisation of the Oyu Tolgoi Porphyry Copper-Gold-Molybdenum Deposits, Mongolia: A Review. Geosci. Front. 2016, 7, 375-407. [CrossRef]

15. Miao, L.; Baatar, M.; Zhang, F.; Anaad, C.; Zhu, M.; Yang, S. Cambrian Kherlen Ophiolite in Northeastern Mongolia and Its Tectonic Implications: SHRIMP Zircon Dating and Geochemical Constraints. Lithos 2016, 261, 128-143. [CrossRef]

16. Lamb, M.A.; Badarch, G. Paleozoic Sedimentary Basins and Volcanic-Arc Systems of Southern Mongolia: New Stratigraphic and Sedimentologic Constraints. Int. Geol. Rev. 1997, 39, 542-576. [CrossRef]

17. Blight, J.H.S.; Cunningham, D.; Petterson, M.G. Crustal Evolution of the Saykhandulaan Inlier, Mongolia: Implications for Palaeozoic Arc Magmatism, Polyphase Deformation and Terrane Accretion in the Southeast Gobi Mineral Belt. J. Asian Earth Sci. 2008, 32, 142-164. [CrossRef]

18. Kröner, A.; Lehmann, J.; Schulmann, K.; Demoux, A.; Lexa, O.; Tomurhuu, D.; Štípská, P.; Liu, D.; Wingat, M.T.D. Lithostratigraphic and Geochronological Constraints on the Evolution of the Central Asian Orogenic Belt in SW Mongolia: Early Paleozoic Rifting Followed by Late Paleozoic Accretion. Am. J. Sci. 2010, 310, 523-574. [CrossRef]

19. Lehmann, J.; Schulmann, K.; Lexa, O.; Corsini, M.; Kröner, A.; Štípská, P.; Tomurhuu, D.; Otgonbator, D. Structural Constraints on the Evolution of the Central Asian Orogenic Belt in SW Mongolia. Am. J. Sci. 2010, 310, 575-628. [CrossRef]

20. Heumann, M.J.; Johnson, C.L.; Webb, L.E.; Taylor, J.P.; Jalbaa, U.; Minjin, C. Paleogeographic Reconstruction of a Late Paleozoic Arc Collision Zone, Southern Mongolia. Bull. Geol. Soc. Am. 2012, 124, 1514-1534. [CrossRef]

21. Wu, G.Y.; Liu, M.; Wang, Y. Palinspastic Reconstruction and Geological Evolution of Permian Residual Marine Basins Bordering China and Mongolia. J. Palaeogeogr. 2014, 3, 219-232. [CrossRef]

22. Yakubchuk, A. Architecture and Mineral Deposit Settings of the Altaid Orogenic Collage: A Revised Model. J. Asian Earth Sci. 2004, 23, 761-779. [CrossRef]

23. Bussien, D.; Gombojav, N.; Winkler, W.; von Quadt, A. The Mongol-Okhotsk Belt in Mongolia-An Appraisal of the Geodynamic Development by the Study of Sandstone Provenance and Detrital Zircons. Tectonophysics 2011, 510, 132-150. [CrossRef]

24. Wang, W.; Tang, J.; Xu, W.L.; Wang, F. Geochronology and Geochemistry of Early Jurassic Volcanic Rocks in the Erguna Massif, Northeast China: Petrogenesis and Implications for the Tectonic Evolution of the Mongol-Okhotsk Suture Belt. Lithos 2015, 218-219, 73-86. [CrossRef]

25. Liu, Y.; Li, W.; Feng, Z.; Wen, Q.; Neubauer, F.; Liang, C. A Review of the Paleozoic Tectonics in the Eastern Part of Central Asian Orogenic Belt. Gondwana Res. 2017, 43, 123-148. [CrossRef]

26. Zorin, Y.A. Geodynamics of the Western Part of the Mongolia-Okhotsk Collisional Belt, Trans-Baikal Region (Russia) and Mongolia. Tectonophysics 1999, 306, 33-56. [CrossRef]

27. Parfenov, L.M. Problems of Tectonies of the Mongol-Okhotsk. Geol. Pac. Ocean. 2001, 16, 797-830.

28. Tomurtogoo, O.; Windley, B.F.; Kröner, A.; Badarch, G.; Liu, D.Y. Zircon Age and Occurrence of the Adaatsag Ophiolite and Muron Shear Zone, Central Mongolia: Constraints on the Evolution of the Mongol-Okhotsk Ocean, Suture and Orogen. J. Geol. Soc. Lond. 2005, 162, 125-134. [CrossRef]

29. Kelty, T.K.; Yin, A.; Dash, B.; Gehrels, G.E.; Ribeiro, A.E. Detrital-Zircon Geochronology of Paleozoic Sedimentary Rocks in the Hangay-Hentey Basin, North-Central Mongolia: Implications for the Tectonic Evolution of the Mongol-Okhotsk Ocean in Central Asia. Tectonophysics 2008, 451, 290-311. [CrossRef]

30. Ruppen, D.; Knaf, A.; Bussien, D.; Winkler, W.; Chimedtseren, A.; von Quadt, A. Restoring the Silurian to Carboniferous Northern Active Continental Margin of the Mongol-Okhotsk Ocean in Mongolia: Hangay-Hentey Accretionary Wedge and Seamount Collision. Gondwana Res. 2014, 25, 1517-1534. [CrossRef]

31. Van der Voo, R.; van Hinsbergen, D.J.J.; Domeier, M.; Spakman, W.; Torsvik, T.H. Latest Jurassic-Earliest Cretaceous Closure of the Mongol-Okhotsk Ocean: A Paleomagnetic and Seismological-Tomographic Analysis. Geol. Soc. Am. Spec. Publ. 2015, 513, 589-606. [CrossRef]

32. Sengör, A.M.C.; Natal'in, B.A.; Burtman, V.S. Evolution of the Altaid tectonic collage and Palaeozoic crustal growth in Eurasia. Nature 1993, 364, 299-306. [CrossRef] 
33. Amelin, Y.; Lee, D.-C.; Halliday, A.N.; Pidgeon, R.T.; Hills, J. Nature of the Earth's earliest crust from hafnium isotopes in single detrital zircons. Nature 1999, 399, 252-255. [CrossRef]

34. Košler, J.; Fonneland, H.; Sylvester, P.; Tubrett, M.; Pedersen, R.B. U-Pb Dating of Detrital Zircons for Sediment Provenance Studies-A Comparison of Laser Ablation ICPMS and SIMS Techniques. Chem. Geol. 2002, 182, 605-618. [CrossRef]

35. Kemp, A.S.; Hawkesworth, C.J.; Foster, G.L.; Paterson, B.A.; Woodhead, J.D.; Hergt, J.M.; Gray, C.M.; Whitehouse, M.J. Magmatic and Crustal Differentiation History of Granitic Rocks from Hf-O Isotopes. Science 2007, 315, 980-983. [CrossRef] [PubMed]

36. Fryer, J.; Jackson, S.E.; Longerich, H.P. The Application of Laser Ablation Microprobe-Inductively Coupled Plasma-Mass Spectrometry (LA-ICP-MS) to in Situ (U)Pb Geochronology. Chem. Geol. 1993, 109, 1-8. [CrossRef]

37. Griffin, W.L.; Belousova, E.A.; Shee, S.R.; Pearson, N.J.; O'Reilly, S.Y. Archean crustal evolution in the northern Yilgarn Craton: U-Pb and Hf-isotope evidence from detrital zircons. Precambrian Res. 2004, 131, 231-282. [CrossRef]

38. Zhou, J.B.; Wilde, S.A.; Zhang, X.Z.; Zhao, G.C.; Liu, F.L.; Qiao, D.W.; Ren, S.M.; Liu, J.H. A >1300 km Late Pan-African Metamorphic Belt in NE China: New Evidence from the Xing'an Block and Its Tectonic Implications. Tectonophysics 2011, 509, 280-292. [CrossRef]

39. Li, S.; Wilde, S.A.; He, Z.; Jiang, X.; Liu, R.; Zhao, L. Triassic Sedimentation and Postaccretionary Crustal Evolution along the Solonker Suture Zone in Inner Mongolia, China. Tectonics 2014, 33, 960-981. [CrossRef]

40. Xu, B.; Zhao, G.; Li, J.; Liu, D.; Wang, B.; Han, Y.; Eizenhöfer, P.R.; Zhang, X.; Hou, W.; Liu, Q. Ages and Hf Isotopes of Detrital Zircons from Paleozoic Strata in the Chagan Obo Temple Area, Inner Mongolia: Implications for the Evolution of the Central Asian Orogenic Belt. Gondwana Res. 2017, 43, 149-163. [CrossRef]

41. Sorokin, A.A.; Zaika, V.A.; Kovach, V.P.; Kotov, A.B.; Xu, W.; Yang, H. Timing of Closure of the Eastern Mongol-Okhotsk Ocean: Constraints from U-Pb and Hf Isotopic Data of Detrital Zircons from Metasediments along the Dzhagdy Transect. Gondwana Res. 2020, 81, 58-78. [CrossRef]

42. Şengör, A.M.C.; Natal-in, B.A.; Sunal, G.; Van Der Voo, R. A New Look at the Altaids: A Superorogenic Complex in Northern and Central Asia as a Factory of Continental Crust Part I: Geological Data Compilation (Exclusive of Palaeomagnetic Observations). Austrian J. Earth Sci. 2014, 107, 169-232.

43. Filippova, I.B.; Bush, V.A.; Didenko, A.N. Middle Paleozoic Subduction Belts: The Leading Factor in the Formation of the Central Asian Fold-and-Thrust Belt. Russ. J. Earth Sci. 2001, 3, 405-426. [CrossRef]

44. Zorin, Y.A.; Sklyarov, E.V.; Belichenko, V.G.; Mazukabzov, A.M. Evolution of Island Arcs and Geodynamics of the Eastern Central Asian Foldbelt in the Neogea. Dokl. Earth Sci. 2007, 412, 39-42. [CrossRef]

45. Safonova, I.; Seltmann, R.; Kröner, A.; Gladkochub, D.; Schulmann, K.; Xiao, W.; Kim, J.; Komiya, T.; Sun, M. A New Concept of Continental Construction in the Central Asian Orogenic Belt: (Compared to Actualistic Examples from the Western Pacific). Episodes 2011, 34, 186-196. [CrossRef]

46. Tang, J.; Xu, W.L.; Wang, F.; Wang, W.; Xu, M.J.; Zhang, Y.H. Geochronology and Geochemistry of Early-Middle Triassic Magmatism in the Erguna Massif, NE China: Constraints on the Tectonic Evolution of the Mongol-Okhotsk Ocean. Lithos 2014, 184-187, 1-16. [CrossRef]

47. Erdenechimeg, D.; Damdinjav, B.; Enkhbayar, B.; Boldbaatar, G. National Geological Map of Mongolia at the Scale of 1:500,000 (MUGZ-500) (37 Lists); Report\#8480; Tumurtogoo, O., Orolmaa, D., Eds.; Geological Investigation Center: Lanzhou, China, 2017.

48. Dolgopolova, A.; Seltmann, R.; Armstrong, R.; Belousova, E.; Pankhurst, R.J.; Kavalieris, I. Sr-Nd-Pb-Hf Isotope Systematics of the Hugo Dummett $\mathrm{Cu}$-Au Porphyry Deposit (Oyu Tolgoi, Mongolia). Lithos 2013, 164-167, 47-64. [CrossRef]

49. Wu, F.Y.; Sun, D.Y.; Ge, W.C.; Zhang, Y.B.; Grant, M.L.; Wilde, S.A.; Jahn, B.M. Geochronology of the Phanerozoic Granitoids in Northeastern China. J. Asian Earth Sci. 2011, 41, 1-30. [CrossRef]

50. Cohen, K.M.; Finney, S.C.; Fan, J.-X. The ICS International Chronostratigraphic Chart. Episodes 2013, 36, 199-204. [CrossRef]

51. Crane, D.; Kavalieris, I. Geologic overview of the Oyu Tolgoi porphyry Cu-Au-Mo deposits, Mongolia. In Geology and Genesis of Major Copper Deposits and Districts of the World-A tribute to Richard H Sillitoe; Hedenquist, J.W., Harris, M., Camus, F., Eds.; Society of Economic Geologists Special Publication: Littleton, CO, USA, 2012; Volume 16, pp. 187-213. 
52. Lamb, M.A.; Cox, D. New ${ }^{40} \mathrm{Ar} /{ }^{39}$ Ar age data and implications for porphyry copper deposits of Mongolia. Econ. Geol. 1998, 93, 524-529. [CrossRef]

53. Perelló, J.; Cox, D.; Garamjav, D.; Sanjdorj, S.; Diakov, S.; Schissel, D.; Munkhbat, T.-O.; Oyun, G. Oyu Tolgoi, Mongolia-Silurian-Devonian porphyry $\mathrm{Cu}-\mathrm{Au}-(\mathrm{Mo})$ and high-sulfidation $\mathrm{Cu}$ mineralization with a Cretaceous chalcocite blanket. Econ. Geol. 2001, 96, 1407-1428. [CrossRef]

54. Kavalieris, I. Notes on 21 samples for zircon U-Pb geochronology from the Oyu Tolgoi Project, South Gobi Desert, Mongolia; Technical Report for Ivanhoe Mines Mongolia; Ivanhoe Mines: Khanbogd, Mongolia, 2005; p. 48.

55. Tolgoi, O. Oyu Tolgoi Geological Summary Report; Internal Technical Report for Ivanhoe Mines Mongolia; Ivanhoe Mines: Khanbogd, Mongolia, 2008; p. 129.

56. Johnson, C.L.; Amory, J.A.; Zinniker, D.; Lamb, M.A.; Graham, S.A.; Affolter, M.; Badarch, G. Sedimentary response to arc-continent collision, Permian, southern Mongolia. In Formation and Applications of the Sedimentary Record in Arc Collision Zones; Draut, A., Clift, P.D., Scholl, D.W., Eds.; Geological Society of America: Boulder, CO, USA, 2007; Volume 436, pp. 363-390.

57. Webb, L.E.; Johnson, C.L. Tertiary Strike-Slip Faulting in Southeastern Mongolia and Implications for Asian Tectonics. Earth Planet. Sci. Lett. 2006, 241, 323-335. [CrossRef]

58. Jian, P.; Liu, D.; Kröner, A.; Windley, B.F.; Shi, Y.; Zhang, W.; Zhang, F.; Miao, L.; Zhang, L.; Tomurhuu, D. Evolution of a Permian intraoceanic arc-trench system in the Solonker suture zone, Central Asian Orogenic Belt, China and Mongolia. Lithos 2010, 118, 169-190. [CrossRef]

59. Xu, B.; Zhao, P.; Wang, Y.; Liao, W.; Luo, Z.; Bao, Q.; Zhou, Y. The Pre-Devonian Tectonic Framework of Xing'an-Mongolia Orogenic Belt (XMOB) in North China. J. Asian Earth Sci. 2015, 97, 183-196. [CrossRef]

60. Zhao, P.; Fang, J.; Xu, B.; Chen, Y.; Faure, M. Early Paleozoic Tectonic Evolution of the Xing-Meng Orogenic Belt: Constraints from Detrital Zircon Geochronology of Western Erguna-Xing'an Block, North China. J. Asian Earth Sci. 2014, 95, 136-146. [CrossRef]

61. Li, S.; Chung, S.L.; Wilde, S.A.; Wang, T.; Xiao, W.J.; Guo, Q.Q. Linking Magmatism with Collision in an Accretionary Orogen. Sci. Rep. 2016, 6, 25751. [CrossRef]

62. Folk, R.L. Petrology of Sedimentary Rocks; Hemphill Publishing Company: Austin, TX, USA, 1974; p. 182.

63. Dickinson, W.R. Interpreting detrital modes of greywacke and arkose. J. Sediment. Petrol. 1970, 40, 695-707. [CrossRef]

64. van Achterberg, E.; Ryan, C.G.; Jackson, S.E.; Griffin, W. Data reduction software for LA652 ICP-MS. In Laser Ablation-ICPMS in the Earth Science: Principles and 653 Applications; Sylvester, P., Ed.; Short Course Series; Mineralogical Association of Canada: Ottawa, ON, Canada, 2001; Volume 29, pp. 239-243.

65. Jackson, S.E.; Pearson, N.J.; Griffin, W.L.; Belousova, E.A. The application of laser ablation-inductively coupled plasma-mass spectrometry to in situ U-Pb zircon geochronology. Chem. Geol. 2004, 211, 47-69. [CrossRef]

66. Sláma, J.; Košler, J.; Condon, D.J.; Crowley, J.L.; Gerdes, A.; Hanchar, J.M.; Horstwood, M.S.A.; Morris, G.A.; Nasdala, L.; Norberg, N.; et al. Plešovice zircon-A new natural reference material for U-Pb and Hf isotopic microanalysis. Chem. Geol. 2008, 249, 1-35. [CrossRef]

67. Ludwig, K.R. ISOPLOT. Free Software. 2009. Available online: http://sourceforge.net/projects/isoplot/ (accessed on 22 September 2020).

68. Blichert-Toft, J.; Albarède, F. The Lu-Hf geochemistry of the chondrites and the evolution of the mantle crust system. Earth Planet. Sci. Lett. 1997, 148, 243-258. [CrossRef]

69. Raymond, L.A. Classification of melanges. In Melanges: Their Origin and Significance; Raymond, L.A., Ed.; Geological Society of America: Boulder, CO, USA, 1984; Volume 198, pp. 7-22.

70. Bars, A.; Miao, L.; Fochin, Z.; Baatar, M.; Aanad, C.; Togtock, K. Petrogenesis and tectonic implication of the Late Mesozoic volcanic rocks in East Mongolia. Geol. J. 2018, 53, 2449-2470. [CrossRef]

71. Peretyazhko, I.S.; Savina, S.A.; Dril, S.I. Early Cretaceous trachybasalt-trachyte-trachyrhyolitic volcanism in the Nyalga basin (Central Mongolia): Sources and evolution of continental rift magmas. Russ. Geol. Geophys. 2018, 59, 1679-1701. [CrossRef]

72. Kurihara, T.; Tsukada, K.; Otoh, S.; Kashiwagi, K.; Chuluun, M.; Byambadash, D.; Boijir, B.; Gonchigdorj, S.; Nuramkhan, M.; Niwa, M.; et al. Upper Silurian and Devonian pelagic deep-water radiolarian chert from the Khangai-Khentei belt of Central Mongolia: Evidence for Middle Paleozoic subduction accretion activity in the Central Asian Orogenic Belt. J. Asian Earth Sci. 2009, 34, 209-225. [CrossRef] 
73. Hara, H.; Kurihara, T.; Tsukada, K.; Kon, Y.; Uchino, T.; Suzuki, T.; Takeuchi, M.; Nakane, Y.; Nuramkhaan, M.; Chuluun, M. Provenance and origins of a Late Paleozoic accretionary complex within the Khangai-Khentei belt in the Central Asian Orogenic Belt, central Mongolia. J. Asian Earth Sci. 2013, 75, 141-157. [CrossRef]

74. Fisher, C.M.; Vervoort, J.D.; Hancharb, J.M. Guidelines for reporting zircon Hf isotopic data by LA-MC-ICPMS and potential pitfalls in the interpretation of these data. Chem. Geol. 2014, 363, 125-133. [CrossRef]

75. Popeko, L.I.; Smirnova, Y.N.; Zaika, V.A.; Sorokin, A.A.; Dril, S.I. Provenance and Tectonic Implications of Sedimentary Rocks of the Paleozoic Chiron Basin, Eastern Transbaikalia, Russia, Based on Whole-Rock Geochemistry and Detrital Zircon U-Pb Age and Hf Isotopic Data. Minerals 2020, 10, 279. [CrossRef]

76. Dumitru, T.A.; Hendrix, M.S. Fission-Track Constraints Constraints on on Jurassic Jurassic Folding Folding and and Thrusting Thrusting in Southern Southern Mongolia Mongolia and and Their Their Relationship Relationship to to the the in Beishan Thrust Thrust Belt Belt of of Northern. Geol. Soc. Am. Mem. 2001, 194, 215-229.

77. Jolivet, M.; Ritz, J.F.; Vassallo, R.; Larroque, C.; Braucher, R.; Todbileg, M.; Chauvet, A. Mongolian Sumits: An Uplifted, Flat, Old but Still Preserved Erosion Surface. Geology 2007, 35, 871-874. [CrossRef]

78. Cunningham, W.D.; Windley, B.F.; Dorjnamjaa, D.; Saandar, M. Late Cenozoic Transpression in Southwestern Mongolia and the Gobi Altai-Tien Shan Connection. Earth Planet. Sci. Lett. 1996, 140, 67-81. [CrossRef]

79. Dobretsov, N.L.; Buslov, M.M.; De Grave, J.; Sklyarov, E.V. Interplay of Magmatism, Sedimentation, and Collision Processes in the Siberian Craton and the Flanking Orogens. Russ. Geol. Geophys. 2013, 54, 1135-1149. [CrossRef]

(C) 2020 by the authors. Licensee MDPI, Basel, Switzerland. This article is an open access article distributed under the terms and conditions of the Creative Commons Attribution (CC BY) license (http://creativecommons.org/licenses/by/4.0/). 